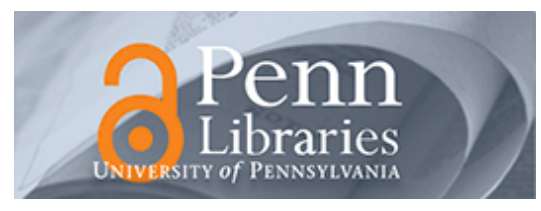

University of Pennsylvania

ScholarlyCommons

Management Papers

Wharton Faculty Research

7-2014

\title{
Knowledge Brokering and Organizational Innovation: Founder Imprinting Effects
}

David H. Hsu

University of Pennsylvania

Kwanghui Lim

Follow this and additional works at: https://repository.upenn.edu/mgmt_papers

Part of the Business Administration, Management, and Operations Commons

\section{Recommended Citation}

Hsu, D. H., \& Lim, K. (2014). Knowledge Brokering and Organizational Innovation: Founder Imprinting Effects. Organization Science, 25 (4), 1134-1153. http://dx.doi.org/10.1287/orsc.2013.0863

This paper is posted at ScholarlyCommons. https://repository.upenn.edu/mgmt_papers/24

For more information, please contact repository@pobox.upenn.edu. 


\title{
Knowledge Brokering and Organizational Innovation: Founder Imprinting Effects
}

\begin{abstract}
We empirically examine the innovation consequences of organizational knowledge brokering, the ability to effectively apply knowledge from one technical domain to innovate in another. We investigate how organizational innovation outcomes vary by founders' initial mode of venture ideation. We then compare how firms established with knowledge-brokering-based ideation differ in their methods of sustaining ongoing knowledge-brokering capacity compared with firms not established in such a manner. We do so by tracking all the start-up biotechnology firms founded to commercialize the then-emergent recombinant DNA technology (the sample of initial knowledge brokers) together with a contemporaneously founded sample of biotechnology firms that did not license the DNA technology (the sample of initial nonbrokers). Our results suggest that (a) ongoing knowledge brokering has an inverted U-shaped relationship with innovative performance in general; (b) initial knowledge brokers have a positive imprinting effect on their organizations' search patterns over time, resulting in superior performance relative to nonbrokers; and (c) initial nonbrokers rely more on external channels of sourcing knowledge, such as hiring technical staff, relative to initial brokers, reinforcing the imprinting interpretation. The described imprinting mechanism differs from extant mechanisms such as partner affiliation- and trigger-based mechanisms in explaining entrepreneurial performance differentials.
\end{abstract}

\section{Keywords}

knowledge brokering, innovation, founder imprinting, entrepreneurship, biotechnology, patents

\section{Disciplines}

Business Administration, Management, and Operations 


\title{
The Antecedents and Innovation Consequences of Organizational Knowledge Brokering Capability
}

\author{
by \\ David H. Hsu ${ }^{*}$ and Kwanghui Lim ${ }^{* *}$
}

January 2009

\begin{abstract}
We empirically examine the antecedents and innovation consequences of organizational knowledge brokering capability, the ability to effectively apply knowledge from one technical domain to innovate in another. We do so by tracking all the start-up biotechnology firms founded to commercialize the then-emergent recombinant DNA technology. We examine how firms' interaction with their external environment helps shape their heterogeneous knowledge brokering capacity, which in turn is associated with uneven ex-post innovative performance. Our results suggest that (a) knowledge brokering capability is achieved by hiring inventors with different technical backgrounds, more so than other boundary-spanning mechanisms typically available to start-ups; (b) knowledge brokering has an inverted U-shaped relationship with innovative performance; and (c) knowledge brokering is especially helpful for innovative performance in more complex technological environments.
\end{abstract}

Keywords: knowledge brokering, innovation, entrepreneurship, biotechnology, patents.

\footnotetext{
* The Wharton School, 2000 Steinberg Hall-Dietrich Hall, University of Pennsylvania, Philadelphia, PA 19104, dhsu@wharton.upenn.edu. **Melbourne Business School, k@kwanghui.com. We thank Kathy Ku of the Stanford University Office of Technology Licensing for allowing us to access the Cohen Boyer patent records. We thank Dan Levinthal, Marvin Lieberman, Hans Pennings, Scott Shane, Olav Sorenson, Scott Stern, and especially three anonymous reviewers for helpful suggestions. We enjoyed valuable conversations with Preeta Banerjee in the early stages of this project. We also thank conference or seminar participants at the Academy of Management, Harvard Business School, MIT, Swiss Federal Institute, UCLA, University of Maryland, USC and Wharton for useful comments. Josh Lerner generously provided access to his biotechnology index. Mike Gonsalves, Zhuang Wenyue, and Tong Zhao provided valuable research assistance. We acknowledge use of the NUS patent database. We thank the Mack Center for Technological Innovation at Wharton, Alfred P. Sloan Foundation, Melbourne Business School and IPRIA.ORG for funding this project.
} 


\section{Introduction}

According to the neoclassical economics view of organizations, given the same resources and environmental conditions, all firms will take the same actions, resulting in undifferentiated performance profiles among the set of firms. Scholars of organizational strategy and entrepreneurship dispute this characterization on two grounds. First, firms may take different actions, even when faced with the same opportunity, as a result of varied entrepreneurial conjectures of the most profitable course of action (Shane, 2000). Firms with different resource endowments are even more likely to take different actions, also leading to heterogeneous performance results. Second, firms' capabilities of converting a given set of opportunities or resources into performance output may also vary. Together, these two critiques comprise the backbone of the resource-based view (RBV) of the firm, which has proven useful in explaining the empirical regularity that there is more variation in organizational performance within an industry as compared to across industries (Nelson, 1991; McGahan and Porter, 1997).

Despite the considerable interest in the RBV (see Barney and Arikan, 2001 and Newbert, 2007 for literature reviews of this voluminous research), the theory is often critiqued for at least two reasons. First, while many studies propose and identify factors correlated with organizational performance, far fewer studies examine the origins of adopting those same practices and the dynamics of capability evolution (see Cockburn, et al. 2000; Ahuja and Katila, 2004; and Cattani, 2005 for exceptions). The prior literature has largely conceptualized capabilities as endowments, exogenous to the analysis (e.g., Shane and Stuart, 2002), yet a fuller understanding of the antecedents to factors associated with performance is important to the RBV theory, as it would not be rational for firms to under-invest in assets or capabilities known to boost performance. Second, capability and performance are often tautologically defined such that evidence for one is taken for the presence of the other. This study aims to address these twin shortfalls by examining the antecedents and innovative impact of a particular organizational competence, knowledge brokering capability, the ability of firms to "profitably transfer ideas from where they are known to where they represent more innovative possibilities" (Hargadon, 1998, p. 214). ${ }^{1}$ We trace the development of this capability from the birth of an industry with a common initial technological trigger (albeit with subsequent branching behavior), which allows us to factor out a range of possibly intervening effects in capability development. We attend to the tautology critique by developing arguments for, and testing the boundary conditions and circumstances under which knowledge brokering capability will be associated with innovative performance. A clear understanding of the link between brokering capability and performance also permits further theorizing about the motivation for uneven ex ante investments into

\footnotetext{
${ }^{1}$ When we use the term "broker," we do not necessarily mean it in the social network sense of bridging structural holes (Burt, 1992). We are concerned with using ideas from one domain to innovate in another, which may take place with or without the presence of structural holes.
} 
developing this capability. For example, if there is not a simple linear relationship between a given capability and performance, we would expect investments in acquiring that capability to vary across firms.

Organizational knowledge brokering capability is important both theoretically and practically, and so we devote our efforts to studying this particular competence. On the theoretical side, a host of papers, starting with March (1991), have argued that organizations need to strike a balance between exploiting their capabilities and exploring new terrain. Exploration is particularly important in fastmoving technological environments which may overturn organizational competencies (Tushman and Anderson, 1986). Yet, when firms conduct exploratory search, they tend to search "locally", exploring knowledge that is familiar and within easy reach from their existing technological and geographic positions (Stuart and Podolny, 1996), which tends to limit the ability of exploratory search to find global performance peaks. Local search behavior has been explored at multiple levels of analysis, with most explanations based on individual-level bounded rationality (March and Simon, 1958) and firm-level routines (Nelson and Winter, 1982). Local search behavior is also perpetuated by "imprinting" by founders of new ventures (Stinchcombe, 1965) and the long-lasting impact of firms' initial conditions (e.g., Baron et al., 1996; Cockburn et al., 2000). Hence, there has been considerable interest in mechanisms which allow firms to move beyond local search (e.g., Rosenkopf and Nerkar, 2001; Rosenkopf and Almeida, 2003). We regard knowledge brokering capability as an important means by which firms can move beyond local search, which conforms with the common theme in this literature that some type of boundary-spanning activity (whether technological or organizational) is necessary for organizations to tap into distributed knowledge domains. We therefore investigate the actions and decisions of new ventures to bolster their knowledge brokering capability.

On the practical side, knowledge brokering is one means of spanning knowledge boundaries which is managerially provocative. The ability to leverage knowledge and expertise in one domain to innovate in another not only economizes on R\&D expenditures (Baldwin and Clark, 2000), but also offers the tantalizing prospects of yielding breakthrough innovations (Hargadon and Sutton, 1997; Hargadon, 1998) and quickening the pace of innovation (Kodama, 1992). Yet, existing research on the topic, while usefully describing a process model of how such brokers successfully organize their activities for product performance, is limited in addressing the research questions of this paper. This is because the prior studies selected their subject organizations for ethnographic observation based on their leadership in brokering. From a strategy and business policy standpoint, however, we would like to understand both why there is a heterogeneous distribution of knowledge brokering ability across firms, even within an industry, and the performance implications of that heterogeneous ability. 
Our empirical strategy is to choose a setting in which firms were founded to exploit a given technological innovation. This design allows us to track firms' temporal patterns of knowledge brokering from their inception while holding initial technology constant. Since path dependencies are important in shaping trajectories of resource attainment, this method allows us to trace a sample of firms' resource trajectories from their birth in commercializing technology stemming from a common technological advance. We can then study the importance of various organizational mechanisms in enhancing firms' knowledge brokering capability, as well as innovative performance consequences of such ability.

The commercialization of recombinant DNA technology via open, non-exclusive licensing of the Cohen-Boyer patent by Stanford University between 1980 and 1997 provides an excellent setting for addressing our research questions. The Cohen-Boyer innovation allowed DNA from two or more sources to be recombined into a single target, and the commercialization of this innovation helped launch the modern biotechnology industry (Kenney, 1986). ${ }^{2}$ Due to generous access to detailed program records by the Stanford University Office of Technology Licensing, and by combining those records with firm and patent-level data from multiple other sources, we create a unique dataset of all de novo start-ups founded to commercialize this technology. Our dataset includes 19 firms (listed in Table 1) that produced 3,652 patented inventions between 1976 and 2004.

We wish to note at the outset some limitations of the empirical setting which shape the interpretation of the results. First, in addition to the limited set of firms under investigation, the entrepreneurial decision to license the Cohen Boyer patent and launch a start-up to commercialize the technology might itself be construed as an act of knowledge brokering. We regard those acts as founding decisions rather than examples of knowledge brokering, which we conceptualize as knowledge reapplication across technical domains. Second, our analysis of the antecedents of knowledge brokering will not include a full cost-benefit analysis, as we do not observe costs of firm actions or internal firm policies and activities across time (as in Henderson and Cockburn, 1994), and so we focus our attention on external boundary-spanning activities used by firms to build knowledge brokering.

We find that knowledge brokering capability relates more strongly to hiring inventors with different technical backgrounds than to other boundary-spanning mechanisms typically available to startups. This analysis recognizes that brokering capability is a function of investments in various boundaryspanning activities, a perspective that is not clearly articulated in the literature. Furthermore, this result

\footnotetext{
${ }^{2}$ The biotechnology industry is technologically dynamic, which makes knowledge brokering and other channels of innovation particularly important. As of 2003, biotechnology innovations accounted for 155 U.S. Federal Drug Administration (FDA) approved drugs, with over 370 biotechnology clinical trials and vaccines in development (BIO website, accessed May 24, 2004). Furthermore, biotechnology firms are a significant source of upstream innovation for pharmaceutical firms (Gans et al., 2002): of the 691 new chemical entities approved by the FDA between 1963 and 1999, 38 percent were licensed by pharmaceutical firms, primarily from biotechnology firms (DiMasi, 2000).
} 
has straightforward managerial implications for investing scarce organizational resources (which is especially salient in the start-up setting). A second set of results relate to the conditions under which knowledge brokering corresponds to innovative performance. We show that an inverted U-shaped relationship exists between brokering and innovative performance, with "wholesale" brokering performing worse than not brokering at all. We also find that knowledge brokering is especially powerful in complex technical environments. These results suggest both that the view from the prior literature that "more knowledge brokering is better" should be more nuanced, but more generally for the RBV, that there is not a linear correspondence between capabilities and organizational performance. Taken together, these results simultaneously deepen our understanding of knowledge brokering and the RBV.

The plan for the remainder of the article is as follows: in Section 2, we develop our arguments for the origins and impact of knowledge brokering. Section 3 discusses the data and method employed, while Section 4 presents the empirical results. A final section discusses the results and implications for the literature and for managers.

\section{Literature and Hypothesis Development}

In this section, we concentrate our discussion of the antecedents and consequences of knowledge brokering at the organizational level. While the processes of knowledge brokering are multi-level, involving individuals, organizations, and networks (Hargadon, 2002), we focus our theorizing to the firm level, as the resource-based theories operate at this level.

\section{A. Organizational Efforts to Bolster Knowledge Brokering Competence}

The behavioral origins of localized organizational search in research and development (R\&D) have been well documented in the literature (see Stuart and Podolny, 1996 and Katila and Ahuja, 2002 for excellent reviews). In brief, search tends to be localized for several reasons. Organizations tend to rely on historic experiences, even when faced with changes in their environments, and so new search efforts are often circumscribed by organizations' own experiences and evolved procedures, resulting in path dependence (Cyert and March, 1963; Nelson and Winter, 1982; Burgelman, 1994). Such organizationlevel standard operating procedures and routines facilitates technology development. Organizational routines can therefore become a source of competence for the firm - hence they are not easily abandoned (Henderson and Clark, 1990).

A second reason for local search and organizations' persistence in search direction, while often not conceptualized in this way, is due to founding team imprinting (Stinchcombe, 1965). Such imprinting can be manifested in firms' policies and procedures as they relate to organizational culture, human resource management, and R\&D practices (Baron et al., 1996). The philosophies and managerial styles of 
founders not only shape organizational identities, but they also influence investment decisions in corporate reputation and recruiting in ways which tend to reinforce the founding philosophies, resulting in distinctive corporate styles, such as "the Hewlett-Packard way" (Packard, 1995).

The above arguments regarding local search suggest that exploratory organizational search is unlikely to occur in the absence of conscious firm effort, serendipity aside (Rosenkopf and Nerkar, 2001; Rosenkopf and Almeida, 2003). Yet, exploratory search is important for competitive success, particularly in fast-paced environments in which technical innovation continuously reconfigures the competitive landscape (March, 1991; Brown and Eisenhardt, 1997; Ahuja and Lampert, 2001). The main insight from the literature is that some boundary (technical, scientific, organizational, or geographic) must be spanned in order for organizations to engage in any type of exploratory search (Rosenkopf and Nerkar, 2001; Rosenkopf and Almeida, 2003; Ahuja and Katila, 2004), and this also applies to knowledge brokering oriented search.

Our goal here is to theorize about the relative effectiveness of three extramural channels by which organizations may span boundaries in an effort to bolster their knowledge brokering capabilities. We focus on external rather than internal modes in organizing for innovation because internal reorientation is much rarer than external boundary-spanning. For example, Mintzberg and Waters (1982) found that strategic reorientation in the entrepreneurial firm they tracked over a long time horizon was rare, but was made more likely when venture growth exceeded the knowledge of the founder. Moreover, Boeker (1989) reports that semiconductor start-ups typically maintained the corporate strategies they had adopted at the time of founding. Cockburn et al. (2000) found organizational "styles" (in their case, the initial extent of science-driven drug discovery by pharmaceutical firms) persist over long periods of time. More generally, the ability to monitor and access external innovations—absorptive capacity—can be critical for firms' resource acquisition and competitive advantage (Cohen and Levinthal, 1990). We therefore concentrate our attention on mechanisms for accessing external knowledge and resources, though we are aware that internal organizational policies can be important means of increasing knowledge brokering. For instance, firms may allow technical staff to publish portions of their research findings in professional journals (Henderson and Cockburn, 1994) and/or set aside dedicated time for exploratory research. ${ }^{3}$

We discuss three extramural boundary-spanning mechanisms typically available to start-ups as avenues for bolstering their access to external ideas and resources: hiring on the technical labor market, affiliating with venture capital (VC) networks, and engaging in equity strategic alliances. We select these three means as opposed to alternatives which are either less available to start-ups (e.g., acquisitions) or

\footnotetext{
${ }^{3}$ Such policies may differ not only in the research latitude given to technical staff ex-ante, but also in the degree to which output monitoring/verification is required ex-post. These internal policies will also have implications for the type of individual attracted to work in such an environment, and so can have implications for accessing external knowledge.
} 
have been characterized by the literature as less effective in knowledge transfer (e.g., technology licensing). A first channel by which organizations might bolster their knowledge brokering ability is to hire technical staff with expertise complementary to that already possessed by the firm (e.g., Almeida and Kogut, 1999; Rosenkopf and Almeida, 2003). Engineers and scientists with distant technological knowledge may be available for hire from the scientific labor market, and so human capital mobility represents a means by which firms can access complementary technical know-how, especially if such knowledge is complex, specialized and/or tacit. Consistent with Polanyi's (1966) observation that individuals know more than they can articulate due to the tacit nature of knowledge, Zucker et al. (1998) found that in the early biotechnology industry, the specialized knowledge possessed by highly accomplished university scientists made them scarce and valuable resources. The fact that these scientists were for the most part geographically immobile helps explain the observed concentration of the industry near academic centers of excellence in biology and chemistry, as well as why this concentration has persisted over time. These same factors have led to the widely-held belief that transferring knowledge (even with the availability of codified sources such as scientific publications or patents) is extremely difficult absent the movement of skilled individuals (e.g., Teece et al., 1997).

A second mechanism by which entrepreneurial organizations may be able to access distant knowledge is by linking into VC networks. VCs represent an important source of financing for innovative start-up firms since they have developed a structure that simultaneously institutes governance mechanisms and provides value-added services for start-up business development (Gompers and Lerner, 1999). An example of the governance mechanism is the practice adopted by VCs of staged financing, in which funds are disbursed in multiple rounds, so that intermediate milestones of business development can be verified after each round and before further funding is disbursed. This is coupled with formal corporate governance via VC representation on the board of directors of the companies they invest in. VCs also provide non-financial value-added services to start-ups as a result of their boundary spanning activities. VCs assemble portfolios of start-up investments, typically covering a non-overlapping product space within a concentrated set of industries. Not only does the concentration help VCs provide technical expertise required in evaluating and providing value to start-ups, it also helps extend the VC's social network in assisting start-ups (Sorenson and Stuart, 2001). Reputable VCs connect their portfolio companies to external resources, such as the capital and labor markets, and also help start-ups in facilitating cooperative relationships (Hsu, 2006; Lindsey, 2008), and more generally lower the transaction costs to knowledge flows. These linkages to the VC and the VC's extended network allow entrepreneurial ventures to broaden their range of technical and organizational exposure, which are important precursors to the ability to broker knowledge, particularly as VC portfolios are typically nonredundant in product space. 
A third means by which organizations may span knowledge boundaries is via equity strategic alliances. Especially in these more "tightly-integrated" alliances, knowledge sharing and learning can be important motivators for entering into an alliance (Khanna et al., 1998). Mowery et al. (1996), Stuart and Podolny (1996), Baum et al. (2000), Gulati (1998), Banerjee (2006) and others have examined strategic alliances as a mechanism for accessing distant knowledge. Gomes-Casseres et al. (2006) use patent citation data to provide empirical support for the link between such alliances and knowledge flows. Particularly for resource-constrained start-ups which have difficulty extending the boundaries of their organizations through vertical integration, alliances may be an important organizational form allowing access to more distant knowledge via collaborative commercialization. Alliance partners contribute skills and experience in diverse technical areas, and the exchange of ideas and people with such partners could result in brokering-based new ideas. Indeed, some analysts have identified equity alliances as a key to competitive advantage: "While external relationships are an effective mechanism to get access to a 'valuable' technological resource, equity ownership plays a very important role in ensuring that this valuable resource also remains unique and difficult to imitate" (Kale and Puranam, 2004: 80).

While equity alliances, relationships with venture capitalists and hiring inventors with different technical backgrounds can increase the knowledge brokering capacity of a firm, which of these is the most effective? We theorize that hiring inventors with different technical backgrounds is more likely than the other two approaches to increase knowledge brokering. A common problem with alliances is that each partner may not contribute its best resources and technical talent to the partnership, though equity ownership in alliances may reduce the risk of opportunism and free-riding among partners. Start-up resource constraints, however, may both limit their ability to engage in equity alliances in the first place and restrict their available attention in governing the collaborative effort. In addition, alliances are motivated by disparate rationale including accessing new markets and geographies, and so they engender costs and benefits that may not be associated with brokering technical knowledge. Finally, when forming an alliance, a firm is gaining access to a bundle of resources that is pre-configured and routinized within the alliance partner, and which may require considerable effort to integrate or align with the resources of the focal organization. Thus, the overall impact of equity alliances on knowledge brokering may not be as great as the more targeted approach afforded by hiring R\&D personnel with different technical skills. The second boundary spanning route, via venture capitalists, while potentially useful in exposing the entrepreneurial firm to complementary knowledge or skills, also may not be as targeted in contributing to knowledge brokering ability as hiring on the technical labor market. Interactions between the new enterprise and the VC are often at the senior levels (top managers interfacing with VC partners). While the resulting VC influence may impact venture policies which may impact possible knowledge brokering competence, the effects are likely not as direct as the hiring mechanism. 
As previously discussed, hiring inventors with prior experience in different technical areas allows a firm to introduce those areas into its existing repertoire of knowledge. Apart from the new employee's direct knowledge being applied within the context of the firm's routines, it also creates opportunities for existing employees to become engaged with and "borrow from" the ideas injected by the new employee. The precision of this approach is likely to exceed equity alliances and VC affiliation because the focal firm can identify people with specific skills in various technical areas and customize the composition of new hires to develop a unique portfolio of knowledge in those areas. Firms can also hire inventors with a track record of brokering knowledge across domains. There is also little substitute for direct personnel involvement, particularly in order to "unstick" highly specialized and tacit technical knowledge. This is consistent with prior research showing the importance of labor mobility in capturing knowledge spillovers, and also the emphasis of hiring "star" scientists even though their outputs are already observable through patents and publications. ${ }^{4}$ We therefore predict:

- Hypothesis 1: hiring inventors with different technical backgrounds will increase a firm's knowledge brokering capability more effectively than either equity strategic alliances or engagement with venture capitalists.

\section{B. Firm Knowledge Brokering and Innovative Performance}

As Hargadon (2002) describes, effective knowledge brokering involves a number of individual, organizational, and network level processes which help orchestrate acquiring, retaining, recalling, recombining, and applying knowledge for commercial success. The literature on organizational learning and memory suggests that such processes can be important capabilities (e.g., Nelson and Winter, 1982; Walsh and Ungson, 1991; Huber, 1991; Kogut and Zander, 1992; Hargadon and Sutton, 1997). While the prior section stressed the view that firms could differentially recognize and invest in building knowledge brokering capability, substantial within-industry performance heterogeneity could also result from either differential use of knowledge brokering ability or a competence in understanding under what circumstances knowledge brokering yields the highest returns. ${ }^{5}$ In this section, we theorize about the relationship between organizational knowledge brokering and innovative performance.

\footnotetext{
${ }^{4}$ A managerial challenge of hiring from disparate domains, however, is to productively integrate such staff into the organization (for example, by effectively organizing them into cross-functional teams). The risk of bringing together people with heterogeneous backgrounds and areas of expertise is that there may be a loss of social cohesion (as a result of different approaches, norms, assumptions and the like), not to mention possibly entrenched organizational power and politics supporting extant organizational processes. These risks can be partially mitigated by developing an organizational culture that promotes experimentation (Thomke, 2003).

${ }^{5}$ There may be intervening factors preventing organizations from transforming their capabilities into performance advantages. These factors may act as indirect inputs into other capabilities or take longer to be manifested into performance differentials (Garud and Nayyagar, 1994; Peteraf and Barney, 2003). We thank an anonymous referee for pointing this out to us.
} 
Work spanning the innovation and organizations literatures has highlighted the possibility that novelty in many different contexts can be derived through recombining a given set of elements. For example, Schumpeter (1934: 65-66) conceptualized the act of innovation itself as the process of "carrying out new combinations," while Usher (1954: 21), in his classic work, argued: "The establishment of new organic relations among ideas, or among material agents, or in patterns of behavior is the essence of all invention and innovation." Most analysts studying this phenomenon have examined it at the invention or technology level of analysis (e.g., Schumpeter, 1934; Basalla, 1988; Kodama, 1992; Levinthal, 1998; and Fleming, 2001). To these scholars, whether they use the term, "recombination," "melding," "fusing," or "speciation event," the act of invention or technology commercialization itself involves the process of recombining existing component ideas for novel output. ${ }^{6}$

Fewer studies have examined the recombination phenomenon at the organizational level. Kogut and Zander (1992) generally conceptualized the act of organizational renewal as the result of recombining organizational capabilities. Hargadon and Sutton (1997) argue that successful organizational knowledge brokering involves the following processes: accessing a wide range of industries with diverse knowledge bases, linking knowledge across industries and contexts, acquiring and storing knowledge into organizational memory, retrieving solutions from organizational memory, and designing solutions which recombine that knowledge. Success in this process requires a supporting organizational culture and structure. Finally, Burt (2004), taking a social network perspective within a firm, finds that compensation, positive performance evaluations, promotions, and good ideas disproportionately accrue to people whose social networks span structural holes. Note that while the focal broker is an individual, the organizational context is critical in the study, and so we have included this study as one of the few in the domain of organizational knowledge brokering.

The takeaway from the disparate literature treating knowledge brokering at various levels of analysis (abstracting from the actual terminology used to describe the phenomenon of knowledge reapplication for productive use across domains) is that positive benefits accrue to such behavior. There is good reason to believe that this relationship also holds true for firms' innovative performance up to a certain point. First, brokering ideas from disparate domains injects greater variation into an organization's internal idea pool, leading to a broader range of ideas available for recombination. This in turn enhances the likelihood that a novel combination critical for innovative performance will be reached. Second, an organizational knowledge brokering "routine" may be established along the lines Hargadon and Sutton (1997) describe for accessing, storing, retrieving, and recombining distant knowledge. This process is

\footnotetext{
${ }^{6}$ Gavetti, et al. (2005) considers the process of strategists' decision making and problem solving via analogical reasoning, which is related to this discussion in that partial analogies can be construed as a form of idea recombination. We return to the concept of analogical reasoning shortly.
} 
likely to work best for less (rather than more) intensive brokering efforts because each of the organizational brokering sub-processes Hargadon and Sutton (1997) describe is easier to achieve the more local is the knowledge to be accessed, stored, retrieved, and recombined. This results both because of the quantities of knowledge involved, and because the corresponding human resource and incentive policies require a less drastic change relative to what would be needed in a more intensive brokering effort (as smaller deviations are closer to the organizational status quo). We will return to this issue shortly at which time we will expand our discussion. Effective organizational knowledge brokering routines can also lead to innovative outcomes as more talented technical staff may be attracted to work for such firms.

Our primary interest is developing the argument that as firms increasingly rely on brokering, the positive relationship between brokering and innovation instead becomes a liability to innovative performance (as this perspective has not been articulated in the literature). Before delving into the details of our arguments for this claim, it will be useful to introduce an important dimension of knowledge brokering which has heretofore been neglected: the degree to which the focal actor uses information and knowledge from other contexts to solve problems in the focal domain. Most studies have examined the presence (or not) of knowledge brokering. We instead conceptualize a spectrum of brokering arrayed by how intensively knowledge is borrowed from other domains to solve problems in the focal domain, ranging from no brokering to wholesale knowledge brokering, with partial brokering in the middle. Wholesale brokering is the act of innovation problem solving borrowing entirely from other domain(s), while no brokering is entirely de novo problem solving.

This conceptualization is helpful in understanding why more intensive knowledge brokering may lead to a downturn in innovative performance. First, more intensive brokering efforts may exhaust the search space, and so efforts at recombination may prove fruitless (e.g., Katila and Ahuja, 2002). Second, there is the risk of recombining inappropriate elements, resulting in poor innovative outcomes. As described by Fleming and Sorenson (2001), variance implies outcomes at both extremes of the distribution - some much better and some much worse. Many possible combinations of elements are not likely to have technical or commercial value, and there are likely significant organizational costs associated with trying to induce recombination-based brokering (such as compromising internal inventive cohesion among disparate technical staff) or conducting the necessary experiments to identify those rare combinations that lead to good outcomes. To yield innovative performance beyond serendipity, more intensive knowledge brokering requires tolerance for experimentation (Thomke, 2003) and measured failure (Manso, 2006), both of which are organizationally costly, as previously discussed. ${ }^{7}$ While an

\footnotetext{
${ }^{7}$ One of the costs of internalizing research and development (we can regard knowledge brokering as a form of R\&D) instead of outsourcing it is that organizations have to pay for innovative effort rather than for results. In an outsourcing relationship, if results are not produced, the supplier does not get paid, whereas engineers and scientists are paid regardless of output within the firm, as $R \& D$ is an inherently risky undertaking (even highly skilled and
} 
experimental approach may allow discarding "failed" experiments, patenting across the distribution of contemporaneous inventions may still take place as the ex-post value of inventions can be difficult to discern ex-ante.

More intensive knowledge brokering can be thought of as increasing reliance on analogical problem solving (see Gavetti et al. 2005 and references therein), hence such brokering is subject to the same pitfalls plaguing analogical problem solving. These factors comprise a third set of reasons for diminished innovative performance resulting from more intensive brokering. First, when relying more intensively on brokering knowledge across contexts, it may be difficult to understand what is truly analogous between the source and target domains. What may superficially appear to be comparable situations may in fact differ along important dimensions critical for successful brokering. Gavetti et al.'s (2005: 694) example of Enron's ill-fated entry into the broadband capacity market based on its earlier success in natural gas and electricity trading is a good illustration of the potential pitfalls of failing to deeply understand the similarities and differences between the source and target contexts.

Second, even with a deep understanding of the source and target contexts, translating, adapting, and tailoring the analogous materials to the problem at hand can be challenging. There are two reasons for this. First, it can be difficult to isolate the functionality and properties of the brokered material outside of the source context, since there might be important interactions between the knowledge module and the source system. This magnifies the challenge of adapting the knowledge for use in the new context, and so it is important to partition the knowledge into a portion that is functionally affected by the surrounding system, and a separate portion that is stand-alone (Baldwin and Clark, 2000). This process is especially challenging the more intensively an organization tries to broker knowledge because a larger knowledge module likely has more system interconnections with the source context.

A second reason why translating analogous knowledge into a new context is difficult, even with a deep understanding of the source and target domains and having pinpointed the functionality of a module, is that simple replication can be surprisingly difficult, even within a firm (Szulanski, 1996). For knowledge replication across organizational boundaries, the challenge can be even more severe, as illustrated by the attempt of US automakers in replicating Japanese lean production systems (Womack et al., 1990). With more intensive knowledge brokering, greater replication is necessary, which implies

motivated scientists can be unlucky in output). Yet according to the RBV, any R\&D asset which can be outsourced cannot be strategic, as strategic assets must be rare, unique and inimitable (and therefore not acquirable on the open market). At issue is the extent to which organizations incur costs in accordance to how drastically they have to change their existing incentive and human resource policies to implement more intensive knowledge brokering efforts. We believe that implementing no knowledge brokering preserves the organizational human resource incentive system, while increasing knowledge brokering intensity magnifies such costs, as more experimentation is necessary to "fine tune" the system. More generally, in innovation settings, firms are less likely to have experience in the target domain, and so it is difficult to be confident of the applicability of both the source and target contexts (Kim et al., 2008). 
commensurate organizational obstacles. To summarize the above arguments, some knowledge brokering can be beneficial for innovative performance, but more intensive knowledge brokering can exhaust the search space, lead to recombining inappropriate elements, and increase the risk of making mistakes during analogical problem solving. We therefore predict:

- Hypothesis 2a: Knowledge brokering will have an inverted U-shaped relationship with firms' innovation performance.

- Hypothesis 2b: Wholesale knowledge brokering will yield worse innovative performance than not employing knowledge brokering at all.

Finally, we are interested in the possible moderating effect of complex technical environments on firms' brokering-led innovative performance. An organization faces a complex technical environment when there are many technical elements, and it is difficult to anticipate the effect of interdependencies and interactions among the elements. Simon (1962, p. 468) defined a complex system as: "one made up of a large number of parts that interact in a non-simple way." When the technical environment is complex, knowledge flows are likely to be more viscous relative to simple environments due to the threat of information loss during transmission (Sorenson et al., 2006). An open question, however, is whether and how technical complexity moderates the relationship between knowledge brokering and innovative performance. We contend that in the face of complex environments, there is a threat that organizations are ironically threatened with paralysis as a result of the multitude of possible technical directions to take.

In complex technical environments, organizational heuristics can help overcome cognitive overload and help constrain the search space (Gavetti and Levinthal, 2000; Gavetti et al. 2005). As in the game of chess where the possible number of moves and ways to play a game are enormous, players resort to pattern recognition and heuristics rather than brute force in guiding their moves. This is the intuition behind the paradox that simple rules are useful organizational templates for managing complexity by allowing for enough organizational structure to capture opportunities, but not being too constraining as to foreclose valuable search (Eisenhardt and Sull, 2001). We therefore anticipate:

- Hypothesis 3: the relationship between firm knowledge brokering and innovative performance is positively moderated by complexity of the technical environment.

\section{Data and Method}

To test these hypotheses, we need an empirical setting in which there is variation in the degree to which a sample of firms have accumulated knowledge brokering capacity (though the firms should not be selected on this basis). As well, we need variation in the firms' innovative output, together with controls for non-knowledge brokering factors that might be associated with innovative performance. It will also be 
useful to examine an empirical context in which the sample is comprised entirely of new ventures, as the literature has argued that established firms have developed sets of organizational routines and may already be on differing resource attainment trajectories. Finally, it would be ideal if the initial technology which the new ventures are seeking to exploit were relatively uniform, as it may be the case that new enterprises may have different inherent abilities to broker knowledge or realize performance outcomes across different starting technologies. In short, we would like to follow a group of new ventures that were founded to exploit a given technological opportunity and to assemble a longitudinal dataset tracking their activities over time.

The commercialization of recombinant DNA by new ventures following its technological discovery in 1973 by University of California-San Francisco scientist Herb Boyer and Stanford scientist Stan Cohen provides a fortuitous empirical context in light of our study requirements. Because the history of the discovery and patenting of the landmark technology is recounted in detail elsewhere (e.g., Reimers, 1987; Hughes, 2001), we will not duplicate those efforts here. Instead, we merely note that Stanford University conducted an open non-exclusive licensing program of the patent (which they advertised in the scientific journals Science and Nature), and so we are able to observe with great precision de novo firms founded to commercialize recombinant DNA technology (users of the technology that did not participate in the licensing program would be infringing the patent and subject to litigation). ${ }^{8}$ Aside from the scientific importance of the Cohen-Boyer invention (opening up the basic technique of recombining DNA), the patent was also clearly important commercially: over its lifetime, the patent yielded approximately $\$ 200 \mathrm{M}$ in licensing revenues, which implies product sales based on the innovation of some \$40B. ${ }^{9}$

A quick comparison of the data used in this study in relation to Hargadon's knowledge brokering studies (1997, 1998, and 2002) will be useful. Hargadon's studies employ a handful of organizations, each of which interfaces with a diversity of clients. For example, several of the organizations are leading design and engineering firms (IDEO and Design Continuum) or consulting firms (McKinsey and Company). These firms are therefore likely to be in privileged positions from the standpoint of coming into contact with disparate communities necessary for knowledge brokering to take place and by virtue of being leaders in their respective fields. These studies, therefore, do not lend themselves to analysis of the

\footnotetext{
${ }^{8}$ The Cohen Boyer invention was covered by three patents, with the most important being a process patent, U.S. patent number 4,237,224, entitled "Process for Producing Biologically Functional Molecular Chimeras." This patent, which formed the core of the Stanford Technology Licensing Office's licensing efforts of recombinant DNA, was issued on December 2, 1980, and expired 17 years later, in 1997. Stanford offered licenses to the patent for a modest fee ( $\$ 10,000$ annual payments, with $0.5 \%$ royalty rates on end products).

${ }^{9}$ Between 1980 and 2000, the patent was cited 235 times by other patents, while the average patent of this vintage in this technology class was cited 9.64 times (Jaffe and Trajtenberg, 2002). Despite the economic value of this patent, which yielded such products as recombinant growth hormone and recombinant insulin, its legal validity was not subsequently challenged.
} 
antecedents to knowledge brokering ability. Furthermore, because the organizations from the Hargadon studies were selected based on their excellence in brokering, it is difficult to infer an empirical relationship between knowledge brokering and innovative impact. While we have chosen our data and empirical context to address these dual challenges, we face a different interpretational issue: Founding teams assembled to capitalize on the Cohen-Boyer patent may have faced different opportunity costs (due to their specialized human capital) relative to other potential entrants.

The comparisons we make in the empirics, however, are among the set of firms which recognized the opportunity and entered the industry, and so we only compare the start-ups observed to have been founded to commercialize the technology among themselves (rather than to an outside set of new ventures). In our first analysis, we evaluate within each of the firms the relative importance of three extramural boundary-spanning mechanisms in bolstering organizational knowledge brokering competence. While access to these channels might be driven by firm quality, we have no ex ante reason to believe that there would be differential access to equity alliances, VC networks, and hiring technical staff among the sampled firms. The analysis of the innovative impact is similarly within the sample of entrants seeking to commercialize recombinant DNA technology. Short of evidence from other studies of knowledge brokering in other settings, we do not know the global generality of the results, however, and so the results should be interpreted with the empirical context in mind. The remainder of this section describes our method and the variables used in the analysis.

\section{A. Sample}

We first identify start-up firms that entered as a result of opportunities to commercialize recombinant DNA technology. We rely on records of licensees to the Cohen Boyer technology from the Stanford University Office of Technology Licensing. We include firms in this sample if: (1) they are de novo firms (as opposed to established pharmaceutical firms), and (2) licensed the Cohen Boyer patents at the time of founding, or within a time window of two years after their founding. This process yielded a total of 19 firms listed in Table 1. We assemble a longitudinal data set by tracing these firms forward in time and recording information on a yearly basis. We conduct two related sets of analyses. First we examine factors that shape each firm's knowledge brokering capacity. Second, we explore innovation consequences of knowledge brokering. Several of the variables used are constructed from patent data, and so it is worth briefly describing the procedure we use in gathering such data.

We identified all U.S. patents granted to the set of firms between January 1976 and December 2004. This resulted in a dataset of 3,652 firm-patent pairs. For each focal patent, we gathered primary patent class information. We then traced backward citations (references made by these patents) to all 
other U.S. patents to construct a measure of knowledge brokering (discussed in the next section). ${ }^{10} \mathrm{We}$ also traced all forward citations (and their primary patent classes) to the focal set of patents through 2004 to construct measures of economic value, in line with standard measures in this literature (e.g., Jaffe and Trajtenberg, 2002). In total, our dataset contains 26,770 backward citations and 22,676 forward citations. For each focal patent, we also record the names and addresses of each inventor (2,901 persons). Finally, we identified all other patents awarded to the same inventors including those obtained while they were at other organizations, thereby building an innovation profile of each inventor over time. ${ }^{11}$ The inventor data allows us to construct measures of inventor-level mobility and knowledge flows between organizations.

The following section describes the variables and empirical tests used in the analyses. The summary statistics and descriptions of all variables are presented in Table 2, and a pair-wise correlation matrix is shown in Table 3.

\section{B. Key Measures}

We follow an established approach of using patent class data to identify the technological position of each invention (e.g. Jaffe, 1986). Knowledge brokering emphasizes the overlap between the technical domain a firm relies upon and the technical area in which it produces new knowledge. For example, Mowery et al. (1996) measure the degree to which two firms overlap in their technical knowledge by measuring the extent to which their patents make cross-citations to one another. Rosenkopf and Nerkar (2001), in the context of optical disk drive firms, use backward citations to non-disk patents as a measure of technological exploration (and non-self citations as a measure of organizational exploration). Because we wish to develop a more flexible measure concerning the knowledge base of the focal invention and measure brokering at the level of the firm instead of each invention, we develop a more general version of the Rosenkopf-Nerkar measure.

We measure firm knowledge brokering as the percentage of citations made by patents applied for (and subsequently granted) that are to primary US classes that the firm did not also receive patents in each year. ${ }^{12}$ For firm $i$ in year $t$, firm knowledge brokering is defined as (the number of backward citations to patents in primary US classes firm $i$ did not patent in during year $t$ ) divided by (the number of backward

\footnotetext{
${ }^{10}$ Approximately $3.5 \%$ of backward citations are to patents issued prior to 1976 . These are not available electronically from the U.S. Patent Office; we therefore used the Delphion database for these data. Consequently, our dataset contains all backward citations regardless of dates.

${ }^{11}$ We found 22,491 patents awarded to inventors with these or similar names. A research assistant was assigned the arduous task of filtering this dataset row by row, identifying each unique inventor based on their names as well as the address of the company the patent was assigned to. The main difficulty encountered was with common names (did an inventor work in multiple firms or did different people with the same name work across those firms?). There are only 41 such inventor names in our database, accounting for 1,142 patents. For these cases, we set a dummy variable to 1 , and this variable is included in the regressions when appropriate as a robustness check.

${ }^{12}$ We thank an anonymous reviewer for proposing this measure.
} 
citations made by firm $i$ in year $t) .{ }^{13}$ High measures of firm knowledge brokering suggest substantial use of technical knowledge originating from outside the firm's own technological base. So as to better approximate the time of invention, we use the application year of each patent to compute this measure, rather than the year the patent was granted.

For the regression analysis, we also create a stock measure of this firm level measure, firm knowledge brokering stock. Since firm knowledge brokering is a fraction, it must be multiplied by the number of patents awarded to firm $i$ in year $t$ to create a stock. Starting from its founding year, each firm's knowledge brokering stock is calculated as the cumulative sum over previous years of (firm knowledge brokering $_{i t} *$ number of patents $\left.{ }_{i t}\right) .{ }^{14}$ Following Argote et al. (1990) and Macher and Boerner (2006), we include an exponential depreciation parameter in computing these stocks. We vary the depreciation parameter from 0 to $20 \%$ to test robustness, in line with the $20 \%$ rate used by Macher and Boerner for the pharmaceutical industry and the $15 \%$ depreciation rate for patent stocks used by Hall et al. (2005) to accommodate the possibility that there could be a degree of organizational "forgetting" over time (e.g., Nelson and Winter, 1982) and to test result robustness.

In order to test our hypothesis on the impact of wholesale knowledge brokering, we create two variables that reflect different degrees of knowledge brokering. These variables are simply special cases of the firm knowledge brokering variable. For each firm, we define wholesale knowledge brokering as the percentage of patents per year that make all of their backward citations to a different primary US class than that of the focal patent. In other words, it is the rate at which a firm generates new patents that depend upon knowledge from other technological areas, but that make no references to knowledge from the same technological class as the focal patent. A second variable, partial knowledge brokering is the percentage of patents per year that make at least one backward citation (but not all of their backward citations) to a different primary US class than that of the focal patent. This variable measures the degree to which the firm creates patented innovation that partly depends upon knowledge from within the same technological area as that of the focal patent, and partly depends upon knowledge from other technological areas. In our regression analysis, we compare the effects of wholesale and partial brokering to the base case in which the firm exhibits no knowledge brokering in a given year, in which case all of its

\footnotetext{
${ }^{13}$ We do not use subclass information in the measure. Because of the large number of subclasses in both the focal and the backward cited patents, calculating a relative measure using all the subclass information becomes computationally difficult. As well, we wish to capture knowledge flowing from other technical areas into that of the focal patent, not from within one sub-specialty to another of the focal patent's technological area. We therefore confine ourselves to primary three digit patent classes rather than sub-classes. There is also the issue of how to treat patents without prior patent references as prior art. Such cases are very rare in our dataset. The empirical results are robust to including an indicator variable for such instances.

${ }^{14}$ Left-censoring is not a problem because all the firms were founded after 1976, the earliest date for which patent data is available in electronic format.
} 
patents make backward citations to the same US patent class as that of each focal patent (the no brokering case represents the base category for our regression analyses).

A measure that is distinct from knowledge brokering but that is often used in the literature is patent originality. This variable is defined as: $O_{i}=\left[1-\sum_{j=1}^{J}\left(\frac{N_{i j}}{N_{i}}\right)^{2}\right]\left(\frac{N_{i}}{N_{i}-1}\right)$, where $i$ indexes the patent, $j$ indexes patent classes, and $N$ represents counts of backward citations (Henderson et al., 1998). The expression outside of the square brackets adjusts for bias associated with small numbers of backward patent counts (Hall and Trajtenberg, 2005). The higher a patent's originality score, the more diverse are its backward citing patents' technological classes. While patent originality is related to knowledge brokering, there are two important differences. First, originality is a patent level measure while our measure of knowledge brokering is at the firm level. Secondly, patent originality measures the breadth of patent classes cited, while knowledge brokering measures the overlap between a firm's own patent classes and those it cites. For example, imagine two firms each with only one patent. Suppose that both patents have originality measures at the minimum value of 0 , with the first patent having all its backward citations concentrated in the same class as the focal patent, while the second patent has all its backward citations concentrated in a different class relative to the focal patent. Despite having the same value for originality, the first case exhibits no firm knowledge brokering while the second one does. Our analysis includes patent originality as a control variable, so as to explore whether firm level knowledge brokering is significant after controlling for patent originality.

To measure recombination complexity, we adopt the approach used by Fleming (2001) and Fleming and Sorenson (2001, 2004). Using the insight that truly novel inventions recombine technical components that have historically not been recombined, Fleming and Sorenson develop a measure of recombination complexity. Each patent may be conceptualized as being composed of components, as reflected by the number of technological subclasses it is assigned $(N)$. The observed ease of recombination of subclass $i$ is defined as $E_{i}$ :

$$
E_{i}=(\# \text { subclasses previously combined with subclass } i \text { ) / (\# previous patents in subclass } i \text { ) }
$$

Next, the coupling of patent $j$ is defined as $K_{j}$ :

$$
K_{j}=(\# \text { subclasses on patent } j) / \sum_{j \in i} E_{i}
$$

The coupling measure is therefore a proxy for how difficult it is to recombine the components in a patent, benchmarked against the historic population of combinations of patent subclasses. A high level of coupling suggests that the focal patent uses subclass combinations that have historically been rarely observed. Finally, the recombinant complexity of each patent is calculated as $C_{i}$ : 


$$
C_{i}=K_{j} / N_{j}=\text { coupling of patent } j / \text { \# subclasses on patent } j
$$

Thus, complexity depends on the number of components in a patent $(\mathrm{N})$ and the extent to which these components are tightly coupled (K), in line with the Kauffman (1993) N-K model it is based upon. This variable serves two purposes in our analyses: it controls for the degree of recombinative difficulty (based on historic distributions), and allows an assessment of how the performance impact of brokering might depend on the complexity of the technical environment.

\section{Variables Used in Analyzing Organizational Antecedents of Knowledge Brokering}

We first investigate organizational factors that shape knowledge brokering capacity at the firmyear level of analysis. In order to test hypothesis 1, we regress firm knowledge brokering stock on three measures of organizational boundary-spanning (beyond a set of firm fixed effects and organizational controls described below).

The first variable, equity alliances stock $(t-2)$, is a proxy for the extent to which firms engage in boundary-spanning via tightly-coupled alliances (those involving equity use). The measure is based on count data, which is sourced from Recombinant Capital (a specialist in biotechnology industry data) and triangulated with the SDC database. A two year lag is assumed, although the results are similar using a one year lag. A second variable, venture capital funding stock $(t-2)$, is a measure of the degree to which VCs, who may offer ventures access to an extended resource network, have funded the entrepreneurial firm (in millions of dollars). The VC data come from the Venture Economics database. The third variable, hired inventors with different technical knowledge stock (t-2), is a measure of the extent to which organizations hired technical staff with a different knowledge base relative to the firm's technical capability at that point in time. We construct this variable using US patent data. For each firm, we first identify all inventors new to the firm in each year, along with all patents awarded to the inventor throughout her career. Among these inventors, we identify those who had previously patented in technological classes different than the ones the firm received patents in within the past five years. ${ }^{15} \mathrm{We}$ then transformed this flow variable into a cumulative stock of new hires with different technical knowledge for each firm-year.

Our analysis includes several control variables. The first control variable, number of therapeutic areas, indicates the number of distinct therapeutic areas in which a firm operates in a given year (as reported by Recombinant Capital). We interpret this variable as a proxy for the firm's scope of operations.

\footnotetext{
${ }^{15}$ We used the five year window to capture the idea that firms would hire people with fairly recent knowledge in different areas in order to effectively broker knowledge. Given the rapid rate of knowledge obsolescence, hiring an active inventor with recent experience in a given technical area may be more beneficial relative to someone who may have worked in that area sometime in the distance past.
} 
A second control variable, funding ease dummy, is based on Lerner's (1994) index of biotechnology funding environment (including funds from $\mathrm{VC}$, initial public offerings and other forms of external funding for biotechnology firms). The funding ease dummy is a proxy for funding environment munificence, and is an indicator of being in an environment in which the index reaches the top $10 \%$ of its distribution. The variable therefore takes a value of one when the funding environment is favorable for biotechnology firms. For start-up firms, resource constraints, such as access to financial and human capital, often limit business development. During periods when the venture capital environment is "hot" and funding is relatively easy to obtain, firms may enjoy more organizational slack and surplus resources, and may therefore experiment and engage in more exploratory search. A third control variable addresses the role of firms' initial search conditions and orientation. A range of theories predict long-lasting organizational effects based on initial conditions (e.g., Stinchcombe, 1965; Baron et al., 1996). In the empirics, we adopt Cockburn et al.'s (2000) philosophy of examining organizational strategy while taking into account the impact of imprinting of initial conditions. We do this by constructing a variable, overlap with initial technology focus, which is defined as the share of firms' patents with the same technology classes with those applied for in its first three years since founding (we select the three year time period to allow for a sufficient window of patent observability; allowing for one or two year time periods yield qualitatively similar results).

\section{Variables Used in Analyzing the Innovation Consequences of Knowledge Brokering}

A second analysis examines the innovation consequences of knowledge brokering as measured by forward patent citations. The variable external forward citations counts the number of external citations to the focal patent within five years of its issue, a well-established measure of innovative impact (Hall et al., 2005; Jaffe and Trajtenberg, 2002). We restrict the forward citation count to those made by external entities (by excluding self-citations) to explore the role of knowledge brokering across organizational boundaries, though the results are generally robust to inclusion of self-forward citations.

The main right hand side variable of interest is the firm knowledge brokering measure. While the earlier analysis utilizes the stock of this variable as a measure of accumulated organizational capability, in examining the consequences of knowledge brokering we utilize the flow of this variable, i.e., we test if the level of firm knowledge brokering for a firm at the time a patent application was filed is correlated with the number of forward citations subsequently received by that patent. We discuss our rationale for this below. We also include the squared term of this variable to test for a quadratic relationship (hypothesis 2a). Measures of partial knowledge brokering and wholesale knowledge brokering are used to test for their effects relative to no brokering (hypothesis $2 b$ ), though we reiterate that these variables merely examine different intensities of knowledge brokering along the same dimension as the firm 
knowledge brokering variable. We also include patent complexity on the right hand side, along with the interaction term of patent complexity and various measures of knowledge brokering in order to test whether brokering is especially important in complex technological environments (hypothesis 3 ).

In the regressions, we control for patent originality and for the number of references to the scientific literature, which indicates the degree of reliance on fundamental scientific knowledge. Sets of dummy variables are used to control for patent application years and primary US patent classes. ${ }^{16}$

\section{Empirical Results}

\section{A. Factors Affecting Firm Knowledge Brokering Stock}

The analysis of firms' efforts to promote knowledge brokering is presented in Table 4. The dependent variable is firm knowledge brokering stock, and the estimation method is firm fixed effects OLS regression, which allows us to mitigate the risk of unobserved time invariant firm characteristics, such as initial founding team quality, overturning the results. Our estimates are therefore based on the within-firm, across time dimension of variation in the panel data. It is worth noting at the outset that we use stock variables for both the dependent and key independent variables. Using stock rather than flow variables recognizes the cumulative nature of search processes and $R \& D$ efforts. Because our level of analysis is a firm-year within a firm fixed effects framework, the estimates essentially reflect the impact of changes in the flows of the key independent variables on the flow of firm knowledge brokering. We lag the independent variables by two years because current period knowledge brokering capabilities likely reflect actions taken in the recent past. While the coefficients we report have not been depreciated (to reflect organizational decay of knowledge and capability), the results are similar for depreciation rates of up to 20 percent.

The first three columns of Table 4 show each of the hypothesized boundary spanning mechanisms, equity alliances stock, VC inflows stock, and hired inventors with different technical knowledge stock. The equity alliance and hiring variables are each individually positive and statistically significant at the 1 percent level, while VC inflows is not statistically significant. Specification 4-4 includes all three mechanisms entered simultaneously, yielding similar coefficients for each variable as when entered individually.

While both the equity alliances stock and hired inventors with different technical knowledge stock effects are both positive and statistically significant, the implied effects from specification (4-4) are as follows: a one standard deviation increase of equity alliances stock is associated with a 4 unit increase in

\footnotetext{
${ }^{16}$ The analysis is also robust to the inclusion of the number of primary patent classes and number of patent subclasses as control variables, which may be proxies for patent scope breadth (Lerner, 1994). We do not include these variables in the tables presented, as they are likely to be an intermediate outcome of the knowledge brokering process. We thank an anonymous reviewer for pointing this out.
} 
knowledge brokering stock, while a one standard deviation increase in hired inventors with different technical knowledge stock corresponds to a 9.3 unit knowledge brokering stock increase (both are evaluated at the means of the other right hand side variables). Thus the results are consistent with hypothesis 1: inventor mobility yields a larger effect on knowledge brokering than either VC networks or alliances, though equity alliances are also important. VC networks in this sample are not correlated with bolstering knowledge brokering stock. We further discuss these results in the concluding section.

The control variables in Table 4 are the number of therapeutic areas, funding ease dummy and overlap with initial technology focus. The number of therapeutic areas variable is positive and statistically significant throughout the specifications, suggesting that knowledge brokering is correlated with organizational scope. The funding ease variable is positive and significant at the $1 \%$ level in all the models, so a munificent funding environment is consistent with knowledge brokering activity. The overlap with initial technology focus variable is negative (though only statistically significant in the first two specifications), which is consistent with the local search and founder imprinting literatures suggesting that firms' initial orientation importantly shapes its subsequent $R \& D$ behavior, in this case knowledge brokering.

\section{B. Innovation Impact of Knowledge Brokering}

In Table 5, we examine the impact of firm knowledge brokering on their innovative performance, with the unit of observation a firm-patent pair. The dependent variable in Table 5 is the number of external forward citations within 5 years of patent issue, a well-established measure of innovative impact (Jaffe and Trajtenberg, 2002). Specifying a citation window of five years post patent issue allows for a meaningful citation comparison across observations.

Since the dependent variable in the analysis is a non-negative count, we estimate Poisson models, as in Hausman et al. (1984) and Hall and Ziedonis (2001). We include both firm- and patent-level variables, so a random effects Poisson model is appropriate and preferable to a negative binomial model (Hilbe, 2008: chapter 10), though in unreported random effects negative binomial models, we find similar results to the ones we report, though with slightly larger standard errors.

The first column, (5-1), reports a parsimonious specification with firm knowledge brokering and its squared term as the main right hand side variables. Using a flow rather than a stock variable for the innovative impact of knowledge brokering matches the dynamic conceptualization of brokering as a capability which can change over time. The estimated coefficient for firm knowledge brokering is positive and significant at the $1 \%$ level while firm knowledge brokering squared is negative and significant, also at the $1 \%$ level. We control for patent originality, which is positive and significant, and sets of dummy variables for patent application years and primary patent classes. Due to the censoring of forward 
citations, it is important to include the patent application year dummies to take into account patent cohorts, which could each have different baseline forward citation rates. ${ }^{17}$ Specification (5-2) adds controls for scale effects via the controls variables firm knowledge stock and number of therapeutic classes and finds the same inverted-U knowledge brokering effect.

The next specification (5-3) introduces a number of additional variables. At the patent level we control for the number of references to the scientific literature (as opposed to references to prior patents), which Fleming and Sorenson (2004) argued can aid in the technological search process. At the firm level we control for the three forms of extramural organizational boundary-spanning we previously discussed, since they may affect the impact of innovations through mechanisms other than their effects on knowledge brokering. These variables are entered without the two year lag used in Table 4 (where we examined their effects on knowledge brokering) because here our aim is to determine whether these variables at the time a patent is applied for have an effect on subsequent innovative impact. The results suggest that all three variables are positive, though hired inventors with different technical knowledge stock has the greatest economic impact on external forward citations, with a one standard deviation increase in such inventors associated with 11.6 additional forward citations.

The main variables of interest, however, are knowledge brokering and its squared term. Across the different models, the former is positive and significant at the 1 percent level while the latter is negative and significant at the same level. This confirms the inverted-U shaped hypothesis between knowledge brokering and external forward cites (hypothesis 2a), which suggests that relatively low levels of brokering injects useful variety into an invention, but that beyond a certain point, brokering can be detrimental to innovative performance. ${ }^{18}$

Specification 5-4 is similar to 5-3, but for the introduction of two variables to test hypothesis $2 \mathrm{~b}$. Wholesale and partial knowledge brokering are compared against the base case of "no brokering" (the omitted category). The estimated coefficient for wholesale knowledge brokering is negative and significant, lending support for hypothesis $2 \mathrm{~b}$. In contrast, partial knowledge brokering has a positive and significant effect relative to no brokering, so a moderate level of knowledge brokering is preferable to none.

\footnotetext{
${ }^{17}$ An alternate approach is to deflate the forward citations by the average value for its scientific field-year cohort as a fixed effect, as discussed in Jaffe and Trajtenberg (2002). Because we do not use the National Bureau of Economic Research dataset for our patent data (this allows us to include more recent patents), we do not use these deflators in our analysis.

${ }^{18}$ Using the estimates from model (5-1), we plot the expected number of forward citations within 5 years of patent issue against firm knowledge brokering, evaluated at the mean values of all the other variables. Figure 1 shows that as firm knowledge brokering increases from 0 to 0.4 , the number of external citations rises, but as firm knowledge brokering continues to increase towards its maximal value of 1 , the number of external citations falls. The yintercept is approximately 2 citations received within five years, but falls to around 1.5 citations when firm knowledge brokering is at its maximum value.
} 
To test hypothesis 3 (whether brokering is especially important for innovation in complex technical environments), models (5-3) and (5-4) include Fleming and Sorenson's (2004) complexity measure, which incorporates as one dimension the degree to which a focal patent uses subclass combinations that have historically been rarely observed (the "coupling" component). Complexity therefore implicitly adjusts for the technological "distance" of the focal invention, at least at the level of the focal patent classes. The estimated coefficient of this variable is negative and statistically significant, consistent with the notion that more complex knowledge resists transfer. The theoretical variable of interest is the interaction of firm knowledge brokering and patent complexity, which is positive and significant. Therefore, technical complexity positively moderates knowledge brokering with innovative performance, as predicted in hypothesis 3. In specification (5-4), we examine the interaction between complexity and different degrees of knowledge brokering. The interaction term between complexity and wholesale knowledge brokering is highly positive and significant at the $1 \%$ level, while the interaction between complexity and partial knowledge brokering is weakly negative (at the $10 \%$ level). This suggests that wholesale knowledge brokering is particularly powerful in complex environments.

\section{Discussion and Conclusions}

We focus our contributions on the resource based view (RBV) of the firm, specifically addressing two often-heard critiques of this theory: first, while many studies propose and identify factors correlated with organizational performance, far fewer studies examine the origins of adopting those same practices and the dynamics of capability evolution. A fuller understanding of the antecedents to factors associated with performance is important to the RBV theory, both because it does not treat those factors as exogenous to the analysis, but also because it would not be rational for firms to under-invest in assets or capabilities known to boost performance. Second, capability and performance are often tautologically defined such that evidence for one is taken for the presence of the other. Our theorizing and empirical evidence suggests a non-linear relationship between knowledge brokering capability, the ability to effectively apply knowledge from one technical domain to innovate in another, and innovative performance. The non-linear association together with the moderating effect of environmental complexity in the brokering-performance relationship provides an understanding for why firms may devote different effort levels to acquiring and exercising knowledge brokering competence. This study therefore addresses two important gaps in the RBV literature by examining the antecedents and innovative impact of knowledge brokering capability.

The commercialization of recombinant DNA technology via non-exclusive licensing offered a fortuitous empirical setting in which initial technology is uniform, and in which multiple new ventures were started in an attempt to exploit that technology. This empirical setting allows us to study the efforts 
of firms in building knowledge brokering capability and its performance implications without the potential confounding effects of diverse initial technologies, firms at different stages of their life cycle, and established organizational routines. Our study therefore complements prior research by examining how firms' interaction with their external environment helps build their heterogeneous knowledge brokering capacity, which in turn is associated with the ex-post uneven innovative performance landscape.

\section{A. Contributions to Research}

In this section, we devote our attention to why our two main contributions to the resource-based theory of organizations are important in deepening our understanding of "why firms differ, and how does it matter?" to borrow Nelson's (1991) title to his influential essay. Our first contribution is in examining the antecedents to factors associated with firm performance instead of treating such capabilities as exogenous to the analysis. Our second contribution is in addressing the critique in the RBV literature that capability and performance are often tautologically defined such that evidence for one is taken for the presence of the other.

With regard to the first contribution, while we are not the first to study the origins and antecedents to heterogeneous resources, we join the few studies (e.g., Cockburn et al., 2000; Ahuja and Katila, 2004; Cattani, 2005) which have explored this issue. Relative to prior studies, we begin our analysis at firms' births, which has the advantage of removing the potentially confounding factor of existing path dependent resource trajectories associated with established organizations. We examine three extramural boundary-spanning mechanisms typically available to start-ups as avenues for bolstering their access to external ideas and resources: hiring on the technical labor market, affiliating with VC networks, and engaging in equity strategic alliances. We select these three means as opposed to alternatives which are either less available to start-ups (e.g., acquisitions) or have been characterized by the literature as less effective in knowledge transfer (e.g., technology licensing). We predict the relative importance of hiring relevant technical talent relative to the other two mechanisms based on theoretical arguments about incentive alignment/governance and effective transfer of tacit knowledge, and our empirical results are consistent with the hypothesized ranking.

The results accord with a theoretical perspective that hiring across disciplines allows a firm to construct its own rare and non-imitable "bundle of resources" comprising these skills, and that while alliances and VC affiliation may facilitate knowledge brokering, they also involve other costs and benefits unrelated to innovation, and are affected by the difficulties of internalizing tacit knowledge. Furthermore, inventor mobility may be much more targeted in that organizations can pinpoint a specific individual with expertise in a given area for hiring. 
Alliances may face the issue of adverse selection, or the "lemons" problem in that partner organizations may not voluntarily give up their most talented personnel and/or technology when arranging a deal with the focal organization, though the equity participation probably mitigates (but does not eliminate) this effect. In addition, when forming an alliance, a firm is gaining access to a bundle of resources that is pre-configured and routinized within the alliance partner, and which may require considerable effort to integrate or align with the resources of the focal organization.

The other boundary-spanning route, via venture capitalists, while potentially useful in exposing the entrepreneurial firm to complementary knowledge or skills, also may not be as targeted in contributing to knowledge brokering ability as hiring on the technical labor market. Interactions between the new enterprise and the $\mathrm{VC}$ are often at the senior levels (top managers interfacing with $\mathrm{VC}$ partners). While the resulting VC influence may impact venture policies, which in turn may impact possible knowledge brokering competence, the effects are likely not as direct as the hiring mechanism.

The analysis is managerially relevant, as resource-constrained start-up entrepreneurs in industries marked by fierce competition often do not have the luxury of organic development of capabilities. They will therefore be especially interested in the most effective means of developing capabilities among the choice set of viable alternatives. The results suggest that there may be little substitute for direct personnel involvement in moving knowledge, particularly in order to "unstick" highly specialized and tacit technical knowledge. This is consistent with prior research showing the importance of labor mobility in capturing knowledge spillovers, and also the emphasis of hiring "star" scientists even though their outputs are already externally observable through patents and publications.

Our second main contribution to the RBV literature is decoupling the concepts of capability and performance. While the prior literature put forward the view that more knowledge brokering is better with respect to a number of organizational outcomes, we theorize and affirm the proposition that the relationship is not straightforward. To arrive at that conclusion, we conceptualized one spectrum of knowledge brokering and explored theoretically and empirically the effect of increasingly intensive knowledge brokering on innovative performance. Most prior studies have examined the presence (or absence) of knowledge brokering, instead of conceptualizing a spectrum of brokering arrayed by how intensively knowledge is borrowed from other domains to solve problems in the focal domain. This can range from no brokering (de novo problem solving) to wholesale knowledge brokering (the act of innovation problem solving borrowing entirely from other domain(s)), with partial brokering in the middle. This is important because knowledge brokering does not exhibit a simple linear relationship with innovation performance. We devote considerable attention in this paper theorizing a curvilinear relationship, including extreme points, between brokerage and innovative performance. While knowledge brokering yields beneficial effects, we argue and empirically affirm an eventual downturn in innovative 
performance with increasing levels of knowledge brokering. This contributes to the RBV by illustrating an approach that decouples the notion of performance from that of capabilities, thereby addressing the tautology critique of the theory.

A related contribution is to the research on problem solving and technological complexity. We show that the complexity of firms' technical environments moderates the relationship between knowledge brokering and innovative performance. These finding inform a recent debate in the theoretical literature on whether analogical reasoning - which corresponds closely in our case to "wholesale" knowledge brokering - is desirable in technologically complex environments (see Gavetti et al., 2005 versus Farjoun, 2008). We show that while both wholesale knowledge brokering and complexity exhibit negative effects on innovation performance, the interaction of these two variables has a positive effect. This result is consistent with our theorizing that in complex technical environments, organizational heuristics can help overcome cognitive overload and help constrain the search space. As in the game of chess where the possible number of moves and ways to play a game are enormous, players resort to pattern recognition and heuristics rather than brute force in guiding their moves. This is the intuition behind the paradox that simple rules are useful organizational templates for managing complexity by allowing for enough organizational structure to capture opportunities, but not being too constraining as to foreclose valuable search (Eisenhardt and Sull, 2001).

The non-linear relationship between brokering and innovation impact, together with the moderating effect of environmental complexity, provides an understanding for why firms may devote different effort levels to acquiring and exercising knowledge brokering competence. Given the uncertain ex-ante value of innovation, we would therefore expect managers to hesitate when investing in knowledge brokering activities, and this could account for why, in Figure 1, the average firm invests in knowledge brokering to a level below that which would produce the maximal innovation impact. The non-linear relationship that we find also informs a large body of work on managing multidisciplinary research (e.g., Jannsen and Goldsworthy, 1995) in which an important issue is the value of cohesion versus diversity (the former is associated with research along disciplinary lines; the latter with interdisciplinary research).

\section{B. Limitations and Future Directions.}

Several limitations of our paper point to interesting future research directions. The debate on the extent to which social interaction is necessary for invention (including knowledge brokering-based invention) is a long-standing one, e.g., Gilfillan (1935) versus Usher (1954), and relates to the individual versus team nature of invention and innovation processes. While anecdotes supporting either view can be offered, it is difficult to empirically adjudicate between these views in our empirical context, as we do not observe unsuccessful patent applications. While surfacing the degree to which social processes matter for 
innovation is an interesting question in its own right, it is one that we do not ask in this paper. To the extent that the extramural boundary-spanning mechanisms we examine as antecedents to knowledge brokering reflect social and business processes, however, this research does inform their relative efficacy in that regard.

A limitation in the analysis of the antecedents to knowledge brokering competence is that there may be omitted variables from the analysis which are time invariant and which are to us unobserved and/or unmeasured. Our firm fixed effects analysis relies on within-firm changes across time to estimate the effect of hiring technical staff, equity strategic alliances, and engagement with VCs in bolstering knowledge brokering. While this method factors out omitted variable bias associated with time invariant factors, we rely on our empirical setting and control variables directly or indirectly to control for a wide range of possibly omitted temporally changing variables. We discuss the role of founder imprinting and organizational inertia, both of which are especially salient in our sample of start-ups, and which would tend to dampen the role of unobserved other effects in shaping knowledge brokering ability. Moreover, in the empirical analysis we directly controlled for the degree to which firms' current knowledge brokering efforts overlap with their initial technology focus, so as to directly capture imprinting/organizational inertia effects. To the extent that there are factors such as differing managerial aspiration levels (e.g., Greve, 1998) and organizational failure factors which might otherwise trigger organization search (Cyert and March, 1963; Bromiley, 1991; Ahuja and Katila, 2004), these might correlate both to the use of our extramural boundary-spanning mechanisms or to our control variable for firm scope, number of therapeutic areas. Finally, while we note that while internal strategic reorientation is rare in organizations, this does not mean that such efforts do not take place, and so internal efforts to bolster knowledge brokering is a fertile area for future research. We will shortly discuss some possible directions for research along these lines. Our hope is that future research will shed light on the costs of internal and external channels of building knowledge brokering capability, such as how firms differ in the costs they face when accessing, storing, retrieving, and brokering knowledge, as such analysis will allow us to more comprehensively assess the phenomenon.

A second issue on the analysis of antecedents to knowledge brokering is the possibility that the results are mainly an artifact of the sample and empirical setting we have chosen. Let us assume for argument's sake that the firms involved in this empirical setting are higher quality than average as a result of their founders' recognition of the entrepreneurial opportunity arising from the Cohen-Boyer patent/invention. However, the comparison we make in the empirics to infer the most effective channels of building knowledge brokering capability is among the set of firms that recognized the opportunity and entered the industry. Furthermore, our empirical exercise is to examine, within each of the firms, the relative importance of these three extramural boundary spanning mechanisms in contributing to 
organizational knowledge brokering competence. Because access to each of the three channels might be driven by firm quality, and because there is no ex ante reason to believe that there would be differential access among the three channels, we do not believe that these results are being driven by selection of this particular empirical setting. Moreover, we know ex-post that while several of the firms were remarkably successful (e.g., Amgen and Biogen), others were clearly failures (Therion and Enzon) ${ }^{19}$, so we do not believe our sample consists of only firms that were successful at knowledge brokering activity. However, absent evidence from other studies of knowledge brokering in other settings (ideally with larger samples), we do not claim complete generality of the results.

While the costs and benefits to patent-based measures have been extensively discussed elsewhere (see for example, Jaffe and Trajtenberg, 2002), we highlight a few issues especially relevant to our context. First, inventors might strategically cite prior art across technical domains to appear more novel, thus improving the likelihood of receiving a patent in the first place. Inventors have an incentive not to over-cite in this manner, however, since doing so will enlarge the relevant prior art, thus narrowing the scope of the patent. Reinforcing this, patent examiners are charged with ensuring relevant citations, since citations are used as a legal device to circumscribe patent scope through the identification of prior art. The ideal way to test for this effect would be to assemble a sample of patent applications, some of which are granted, others of which are not-and look for differences based on prior art. Without conducting a welldesigned study on the topic, however, we are not prepared to speculate on potential bias from this issue.

A second issue relates to the reliability of patent citations as a measure. Alcacer and Gittelman (2006) argue that patent examiner-imposed citations may be an important phenomenon. Hence, our knowledge brokering measures may not accurately represent search behavior by scientists and organizations. On the one hand, patent examiners may "fill the gaps" and add citations to knowledge that inventor(s) did not actually rely upon, biasing our measure. On the other hand, patent examiners may include similar citations that simply track those of the inventor(s) but which do not add any bias. Because the data on patent examiner-imposed citations are only available since 2001, we are not able to empirically examine the extent to which this phenomenon holds in our sample. Recent work by Criscuolo and Verspagen (2008) suggests that while examiner-imposed citations are significant in terms of the geographic concentration of knowledge, the difference between examiner and inventor citations is not statistically significant in terms of technological similarity, after self-citations are removed. Further detailed research will be needed to determine what bias (if any) is introduced by examiner-imposed citations on our measures of knowledge brokering. ${ }^{20}$

\footnotetext{
${ }^{19}$ Therion was closed and sold its assets after the failure of its cancer drug trials in 2006; Enzon which went through a failed merger with NPS Pharmaceuticals in 2004.

${ }^{20}$ Thompson and Fox-Kean (2005) raise concerns over the patent matching procedure used by Jaffe et al. (1993). In their study of the geographic localization of knowledge spillovers, Jaffe et al. use patent citations to create a
} 
We conclude with some possible directions for future research in this domain. While we have taken a first step in this study at empirically accounting for prior access to knowledge brokering search, we believe that this issue needs more systematic attention in the literature. This relates to differential organizational costs of building knowledge brokering capabilities discussed above, as well as to differential firm-level productivity for a given level of investment in organizational knowledge brokering capability. Second, while we have concentrated our attention on external correlates of knowledge brokering, future efforts to understand the efficacy of internal policies and procedures would be welcome. For example, to what extent do firm policies such as allowing scientists to engage in the broader scientific community (e.g., Henderson and Cockburn, 1994), setting aside time for engaging in scientific endeavors (such as at 3M, Google, and IBM), and/or establishing within-firm knowledge sharing mechanisms (e.g., Vara, 2007) result in more knowledge brokering, and with what costs? Third, it would be useful to examine the knowledge brokering phenomenon in other arenas to better understand the generality of our results, particularly given the relatively modest sample size in this study. Finally, we end with a call for better understanding the interaction between individual and organizational level knowledge brokering. Firms can take a number of steps to promote brokering at the organizational level. These range from the external mechanisms studied here, together with internal efforts such as building a corporate culture and instituting policies and organizational design choices. Individuals, however, are the ones carrying out inventive activities. Establishing a "baseline" amount of knowledge brokering will be important, as serendipity and other factors may give rise to organic brokering. Exploring these and other multi-level knowledge brokering mechanisms would deepen our understanding of this form of R\&D search.

matched sample, which they use to control for the pre-existing distribution of inventive activity. The empirical design in our paper does not rely on constructing such patent citation-based matched samples. 


\section{References}

Ahuja, G. and R. Katila (2004). "Where Do Resources Come From? The Role of Idiosyncratic Situations," Strategic Management Journal, 25: 887-907.

Ahuja, G. and C. Lampert (2001). "Entrepreneurship in the Large Corporation: A Longitudinal Study of How Established Firms Create Technological Breakthroughs," Strategic Management Journal, 22: 521543.

Alcacer, J. and M. Gittelman (2006). "Patent Citations as a Measure of Knowledge Flows: The Influence of Examiner Citations," Review of Economics and Statistics, 88: 774-779.

Almeida, P. and B. Kogut (1999). "Localization of Knowledge and the Mobility of Engineers in Regional Networks," Management Science, 45: 905-917.

Argote, L., S. Beckman, and D. Epple. (1990). "The Persistence and Transfer of Learning in Industrial Settings," Management Science, 36(2): 140-154.

Baldwin, C. and K. Clark (2000). Design Rules: The Power of Modularity. MIT Press: Cambridge, MA.

Banerjee, P. (2006). "Learning from the Banyan Tree: Branching Through Cross-Application as a Strategy for High-Tech Entrepreneurial Innovation," Ph.D. dissertation, Wharton School, University of Pennsylvania.

Barney J.B. and A.M. Arikan (2001). "The Resource-Based View: Origins and Implications," in The Blackwell Handbook of Strategic Management, Hitt MA, Freeman RE, Harrison JS (eds). Blackwell: Oxford, UK; 124-188

Baron, J.N., M.D. Burton, and M.T. Hannan (1996). "The Road Taken: Origins and Evolution of Employment Systems in Emerging Companies," Industrial and Corporate Change, 5: 239-275.

Basalla, G. (1988). The Evolution of Technology. Cambridge University Press: Cambridge, UK.

Baum, J., T. Calabrese and B.S. Silverman (2000). "Don't go it Alone: Alliance Network Composition and Startups' Performance in Canadian Biotechnology," Strategic Management Journal, 21: 267-294.

Boeker, W. (1989). "Strategic Change: The Effects of Founding and History, Academy of Management Journal, 32: 489-515.

Bromiley, P. (1991). "Testing a Causal Model of Corporate Risk Taking and Performance," Academy of Management Journal, 34: 37-59.

Brown, S.L. and K.M. Eisenhardt (1997). "The Art of Continuous Change: Linking Complexity Theory and Time-Paced Evolution in Relentlessly Shifting Organizations," Administrative Science Quarterly, 42: $1-34$.

Burgelman, R. (1994). "Fading Memories: A Process Theory of Strategic Business Exit in Dynamic Environments," Administrative Science Quarterly, 39: 24-56.

Burt, R.S. (1992). Structural Holes. Harvard University Press: Cambridge, MA. 
Burt, R.S. (2004). "Structural Holes and Good Ideas,” American Journal of Sociology, 110(2): 349-399.

Cattani, G. (2005). "Preadaptation, Firm Heterogeneity, and Technological Performance: A Study on the Evolution of Fiber Optics, 1970-1995," Organization Science, 16: 563-580.

Cockburn, I., R. Henderson, and S. Stern (2000). "Untangling the Origins of Competitive Advantage," Strategic Management Journal, 21: 1123-1145.

Cohen, W.C. and D.A. Levinthal (1990). “Absorptive Capacity: A New Perspective on Learning and Innovation," Administrative Science Quarterly, 35: 128-152.

Criscuolo, P. and B. Verspagen (2008). "Does it Matter Where Patent Citations Come From? Inventor vs. Examiner Citations in European Patents," Research Policy, 37:1892-1908.

Cyert, R.M. and J.G. March (1963). A Behavioral Theory of the Firm. Blackwell Publishers: Malden, MA.

DiMasi, J.A. (2000). "New Drug Innovation and Pharmaceutical Industry Structure: Trends in the Output of Pharmaceutical Firms," Drug Information Journal 34: 1169-1194.

Eisenhardt, K.M. and D.N. Sull (2001). "Strategy as Simple Rules", Harvard Business Review, January, pp. 107-116.

Farjoun, M. (2008). "Strategy Making, Novelty and Analogical Reasoning - Commentary on Gavetti, Levinthal and Rivkin (2005)," Strategic Management Journal, 29: 1001-1016.

Fleming, L. (2001). "Recombinant Uncertainty in Technological Search," Management Science, 47: 117132.

Fleming, L. and O. Sorenson (2001). "Technology as a Complex Adaptive System: Evidence from Patent Data," Research Policy, 30: 1019-1039.

Fleming, L. and O. Sorenson (2004). "Science as a Map in Technological Search," Strategic Management Journal, 25: 909-928.

Gans, J.S., D.H. Hsu and S. Stern (2002). "When Does Start-up Innovation Spur the Gale of Creative Destruction?" RAND Journal of Economics, 33: 571-586.

Garud, R. and P.R. Nayyar (1994). "Transformative Capacity: Continual Structuring by Intertemporal Technology Transfer," Strategic Management Journal, 15: 365-385.

Gavetti, G. and D. Levinthal (2000). "Looking Forward and Looking Backward: Cognitive and Experiental Search,” Administrative Science Quarterly, 45: 113-137.

Gavetti, G., D. Levinthal and J. Rivkin (2005). "Strategy Making in Novel and Complex Worlds: The Power of Analogy," Strategic Management Journal, 26: 291-712.

Gilfillan, S.C. (1935). The Sociology of Invention. MIT Press: Cambridge, MA. 
Gomes-Casseres, B., J. Hagedoorn, and A.B. Jaffe (2006). "Do Alliances Promote Knowledge Flows?" Journal of Financial Economics, 80: 5-33.

Gompers, P. and J. Lerner (1999). The Venture Capital Cycle. MIT Press: Cambridge, MA.

Greve, H.R. (1998). "Performance, Aspirations, and Risky Organizational Change," Administrative Science Quarterly, 43: 58-86.

Gulati, R. (1998). “Alliances and Networks,” Strategic Management Journal, 19: 293-317.

Hall, B.H. and R.H. Ziedonis (2001), "The Patent Paradox Revisited: An Empirical Study of Patenting in the U.S," RAND Journal of Economics, 32:101-128.

Hall, B, A.B. Jaffe, and M. Trajtenberg (2005). "Market Value and Patent Citations," RAND Journal of Economics, 36:16-38.

Hall, B. and M. Trajtenberg (2005). "Uncovering GPTs Using Patent Data," in Antonelli, Foray, Hall, and Steinmueller (eds.), Festschrift in Honor of Paul A. David, Edward Elgar.

Hargadon, A. and R. Sutton (1997). "Technology Brokering and Innovation in a Product Development Firm," Administrative Science Quarterly, 42: 716-749.

Hargadon, A. (1998). "Firms as Knowledge Brokers: Lessons in Pursuing Continuous Innovation," California Management Review, 40: 209-227.

Hargadon, A. (2002). "Brokering Knowledge: Linking Learning and Innovation," Research in Organizational Behavior, 24:41-85.

Hausman, J., B.H. Hall and Z. Griliches (1984). "Economic Models for Count Data with Application to the Patet-R\&D Relationship," Econometrica, 52(4):909-938.

Henderson, R.M. and K.B. Clark (1990). "Architectural Innovation: The Reconfiguration of Existing Product Technologies and the Failure of Established Firms," Administrative Science Quarterly, 35: 9-30.

Henderson, R.M. and I. Cockburn (1994). "Measuring Competence? Exploring Firm Effects in Pharmaceutical Research,” Strategic Management Journal, 15: 63-84.

Henderson, R.M., A. Jaffe, and M. Trajtenberg (1998). "Universities as a Source of Commercial Technology: A Detailed Analysis of University Patenting, 1965-1988," The Review of Economics and Statistics, 80: 119-127.

Hilbe, J.M. (2008). Negative Binomial Models. Cambridge University Press: Cambridge, UK.

Hsu, D.H. (2006). "Venture Capitalists and Cooperative Start-up Commercialization Strategy," Management Science, 52: 204-219.

Huber, G.P. (1991). "Organization Learning: The Contributing Processes and the Literatures," Organization Science, 2: 88-115.

Hughes, S.S. (2001). "Making Dollars out of DNA: The First Major Patent in Biotechnology and the Commercialization of Biotechnology," Isis, 92: 541-575. 
Jaffe, A. (1986). “Technological Opportunity and Spillovers of R\&D: Evidence from Firms' Patents, Profits, and Market Value," American Economic Review, 76: 984-1001.

Jaffe, A., M. Trajtenberg, and R.M. Henderson (1993). "Geographic Localization of Knowledge Spillovers as Evidenced by Patent Citations," Quarterly Journal of Economics, 108: 577-598.

Jaffe, A. and M. Trajtenberg (2002). Patents, Citations, and Innovations: A Window on the Knowledge Economy. MIT Press: Cambridge, MA.

Jannsen, W., and P. Goldworthy (1995). "Multidisciplinary Research for Natural Resource Management: Conceptual and Practical Implications," Agricultural Systems, 51: 259-279.

Kale, P. and P. Puranam (2004). "Choosing Equity Stakes in Technology Sourcing Relationships: An Integrative Framework," California Management Review, 46(3): 77-99.

Katila, R. and G. Ahuja (2002). "Something Old, Something New: A Longitudinal Study of Search Behavior and New Product Introduction," Academy of Management Journal, 45: 1183-1194.

Kauffman, S.A. (1993). The Origins of Order: Self-organization and Selection in Evolution. Oxford University Press: New York, NY.

Kenney, M. (1986). Biotechnology: The University-Industry Complex. Yale University Press: New Haven, CT.

Khanna, T., R. Gulati, and N. Nohria (1998). "The Dynamics of Learning Alliances: Competition, Cooperation, and Relative Scope," Strategic Management Journal, 19: 193-210.

Kim, J., P.H. Kim and J. O’Toole (2008). "Bounded by Legacy: Prior Experience, Analogical Reasoning, and Institutional Creation," working paper, University of Wisconsin.

Kodama, F. (1992). “Technology Fusion and the New R\&D," Harvard Business Review, 70: 70-78.

Kogut, B. and U. Zander (1992). "Knowledge of the Firm, Combinative Capabilities, and the Replication of Technology," Organization Science, 3: 383-397.

Lerner, J. (1994). "The Importance of Patent Scope: An Empirical Analysis," RAND Journal of Economics, 25: 319-333.

Levinthal, D.A. (1998). "The Slow Pace of Rapid Technological Change: Gradualism and Punctuation in Technological Change," Industrial and Corporate Change, 7: 217-247.

Lindsey, L. (2008). "Blurring Firm Boundaries: The Role of Venture Capital in Strategic Alliances," Journal of Finance, 63: 1137-1168.

Macher, J. and C.S. Boerner (2006). "Experience and Scale and Scope Economies: Trade-offs and Performance in Development," Strategic Management Journal, 27: 845-865.

Manso, G. (2006). “Motivating Innovation,” working paper, MIT Sloan School of Management. 
March, J.G. (1991). "Exploration and Exploitation in Organizational Learning," Organization Science, 2: 71-87.

March, J.G. and H.A. Simon (1958). Organizations. John Wiley: New York.

McGahan, A.M. and M.E. Porter (1997). "How Much Does Industry Matter, Really?" Strategic Management Journal, 18: 15-30.

Mintzberg, H. and J.A. Water (1982). "Tracking Strategy in an Entrepreneurial Firm," Academy of Management Journal, 25: 465-499.

Mowery, D.C., J.E. Oxley and B.S. Silverman (1996). "Strategic Alliances and Interfirm Knowledge Transfer," Strategic Management Journal, 17: 77-91.

Nelson, R.R. and S.G. Winter (1982). An Evolutionary Theory of Economic Growth. Harvard University Press: Cambridge, MA.

Nelson, R.R. (1991). "Why Do Firms Differ, and How Does It Matter?” Strategic Management Journal, 12: 61-74.

Newbert, S.L. (2007). "Empirical Research on the Resource-Based View of the Firm: An Assessment and Suggestions for Future Research," Strategic Management Journal, 28: 121-146.

Packard, D. (1995). The HP Way: How Bill Hewlett and I Built Our Company. HarperBusiness: New York.

Peteraf, M.A. and J.B. Barney (2003). "Unraveling the Resource-Based Tangle," Managerial and Decision Economics, 24: 309-323.

Polanyi, M. (1966). The Tacit Dimension. Anchor Day Books: New York.

Reimers, N. (1987). "Tiger by the Tail," Chemtech, 17: 464-471.

Rosenkopf, L. and A. Nerkar (2001). "Beyond Local Search: Boundary-Spanning, Exploration, and Impact in the Optical Disk Industry," Strategic Management Journal, 22: 287-306.

Rosenkopf, L. and P. Almeida (2003). "Overcoming Local Search Through Alliances and Mobility," Mangement Science, 49: 751-766.

Schumpeter, J. (1934). The Theory of Economic Development: An Inquiry into Profits, Capital, Credit, Interest and the Business Cycle. Harvard University Press: Cambridge, MA.

Shane, S. (2000). "Prior Knowledge and the Discovery of Entrepreneurial Opportunities," Organization Science, 11: 448-469.

Shane, S. and T. Stuart (2002). "Organizational Endowments and the Performance of University Startups," Management Science, 48: 154-170.

Simon, H.A. (1962). "The Architecture of Complexity," Proceedings of the American Philosophical Society, 106: 467-482. 
Sorenson, O., J.W. Rivkin, and L. Fleming (2006). "Complexity, Networks and Knowledge Flow," Research Policy, 35: 994-1017.

Sorenson, O. and T.E. Stuart (2001). "Syndication Networks and the Spatial Distribution of Venture Capital Investments," American Journal of Sociology, 106(6): 1546-1588.

Stinchcombe, A.L. (1965). "Social Structure and Organizations," in Handbook of Organizations, J. March (ed.), Rand-McNally: Chicago, IL, 142-193.

Stuart, T.E. and J.M. Podolny (1996). "Local Search and the Evolution of Technological Capabilities," Strategic Management Journal, 17: 21-38.

Szulanski, G. (1996). "Exploring Internal Stickiness: Impediments to the Transfer of Best Practice Within the Firm," Strategic Management Journal, 17: 27-43.

Teece, D.J., G. Pisano and A. Shuen (1997). "Dynamic Capabilities and Strategic Management," Strategic Management Journal, 18(7): 509-533.

Thomke, S.H. (2003). Experimentation Matters: Unlocking the Potential of New Technologies for Innovation. Harvard Business School Press: Boston, MA.

Thompson, P. and M.E. Fox-Kean (2005). "Patent Citations and the Geography of Knowledge Spillovers: A Reassessment," American Economic Review, 95: 450-460.

Tushman, M.L. and P. Anderson (1986). "Technological Discontinuities and Organizational Environments," Administrative Science Quarterly, 31: 439-465.

Usher, A.P. (1954). A History of Mechanical Inventions, $2^{\text {nd }}$ edition, Harvard University Press: Cambridge, MA.

Vara, V. (2007). "Wikis at Work: Companies Turn the Wikipedia Concept into a Powerful CorporateInformation Tool for Employees," Wall Street Journal, June 18, p. R11.

Walsh, J.P. and G.R. Ungson (1991). "Organizational Memory," Academy of Management Review, 16: 57-91.

Womack, J.P., D. Roos and D.T. Jones (1990). The Machine that Changed the World. Rawson: New York.

Zucker, L., M. Darby and M. Brewer (1998). "Intellectual Human Capital and the Birth of U.S. Biotechnology Enterprises," American Economic Review, 88: 290-306. 
Figure 1: Predicted External Forward Cites within 5 years of Patent Issue (at the Mean Value of Other Variables)

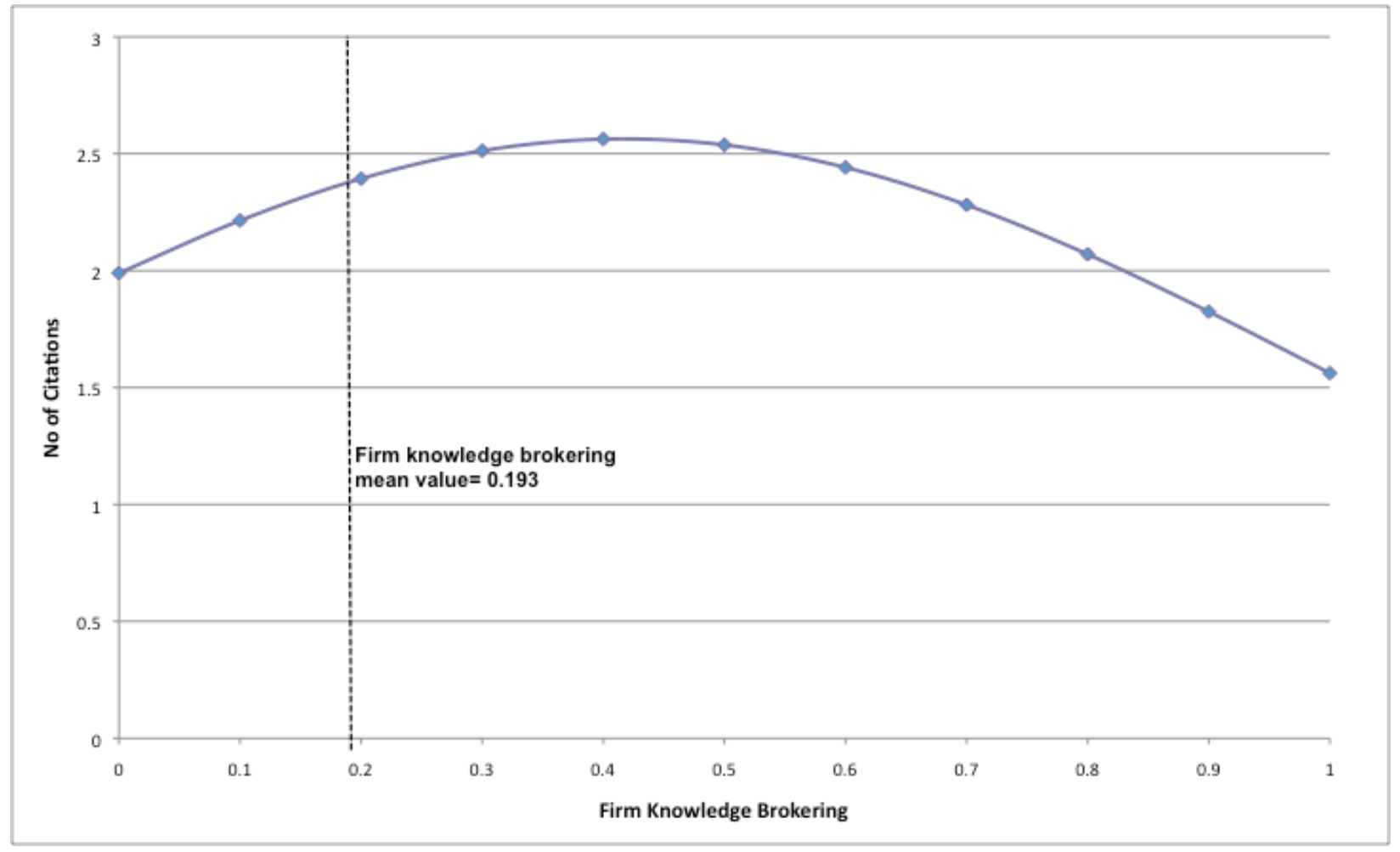


Table 1: List of Firms Included in the Study

\begin{tabular}{|c|c|c|c|}
\hline Firm\# & Firm & Founded & Headquarters Location \\
\hline 1 & Amgen & 1980 & Thousand Oaks, CA \\
\hline 2 & Biogen & 1978 & Cambridge, MA \\
\hline 3 & Celltech & 1980 & Cambridge, UK \\
\hline 4 & Chiron & 1981 & Emeryville, CA \\
\hline 5 & Genelabs & 1983 & Redwood City, CA \\
\hline 6 & Genzyme & 1981 & Cambridge, MA \\
\hline 7 & Mycogen & 1982 & San Diego, CA \\
\hline 8 & DNA Plant Technology & 1980 & Oakland, CA \\
\hline 9 & Genentech & 1976 & San Francisco, CA \\
\hline 10 & Genetics Institute & 1980 & Boston, MA \\
\hline 11 & New England Biolabs & 1978 & Ipswich, MA \\
\hline 12 & Repligen Corp & 1981 & Waltham, MA \\
\hline 13 & Creative Biomolecules & 1981 & Hopkinton, MA \\
\hline 14 & GenPharm International & 1988 & Mountain View, CA \\
\hline 15 & Therion Biologics & 1991 & Cambridge, MA \\
\hline 16 & VYSIS, Inc & 1991 & Downers Grove, IL \\
\hline 17 & Neurex & 1986 & Menlo Park, CA \\
\hline 18 & Enzon & 1981 & Bridgewater, NJ \\
\hline 19 & ICOS Corporation & 1989 & Bothwell, WA \\
\hline
\end{tabular}


Table 2

Summary Statistics and Variable Definitions

\begin{tabular}{|c|c|c|c|}
\hline VARIABLE & DEFINITION & MEAN & SD \\
\hline \multicolumn{4}{|l|}{ Variables used in Table 4} \\
\hline Firm knowledge brokering stock & $\begin{array}{l}\text { Stock of firm-year aggregation of firm knowledge brokering } \\
\text { (see below and text) }\end{array}$ & 15.67 & 16.46 \\
\hline Equity alliances stock & $\begin{array}{l}\text { Stock of number of equity-based strategic alliances formed by } \\
\text { each firm in a given year. }\end{array}$ & 1.05 & 1.52 \\
\hline Venture capital inflows stock & $\begin{array}{l}\text { Cumulative venture capital funding received by the firm in a } \\
\text { given year (millions of dollars) }\end{array}$ & 9.07 & 11.68 \\
\hline $\begin{array}{l}\text { Hired inventors with different } \\
\text { technical knowledge stock }\end{array}$ & $\begin{array}{l}\text { Number of inventors who apply for patents at the focal firm in } \\
\text { a given year who also have prior patenting experience in } \\
\text { different technical areas at another organization }\end{array}$ & 12.18 & 11.51 \\
\hline Number of therapeutic areas & $\begin{array}{l}\text { Number of therapeutic areas in which the firm participates } \\
\text { each year }\end{array}$ & 3.14 & 4.08 \\
\hline Funding ease dummy & $\begin{array}{l}\text { Dummy = } 1 \text { (in a given year) if the external funding } \\
\text { environment is in the top } 10 \% \text { in munificence as measured by } \\
\text { Lerner's biotechnology index. }\end{array}$ & 0.34 & 0.48 \\
\hline $\begin{array}{l}\text { Overlap with initial technology } \\
\text { focus }\end{array}$ & $\begin{array}{l}\text { Share of firm's patents in a given year that are in the same } \\
\text { technology classes as those applied for by the firm during the } \\
\text { first three years since its founding }\end{array}$ & 0.59 & 0.37 \\
\hline \multicolumn{4}{|c|}{ Additional variables used in Table 5} \\
\hline External forward citations & $\begin{array}{l}\text { Number of external forward citations received by a patent } \\
\text { within } 5 \text { years of patent grant year }\end{array}$ & 2.43 & 3.65 \\
\hline Firm knowledge brokering & $\begin{array}{l}\text { For each firm in a given year, this is the percentage of } \\
\text { citations made by patents applied for (and subsequently } \\
\text { granted) that are to primary US classes that the firm did not } \\
\text { also receive patents in that year }\end{array}$ & 0.19 & 0.19 \\
\hline Wholesale knowledge brokering & $\begin{array}{l}\text { For each firm, the percentage of patents per year that make all } \\
\text { of their backward citations to a different primary US class } \\
\text { than that of the focal patent }\end{array}$ & 0.48 & 0.21 \\
\hline Partial knowledge brokering & $\begin{array}{l}\text { For each firm, the percentage of patents per year that make at } \\
\text { least one backward citation (but not all of their backward } \\
\text { citations) to a different primary US class than that of the focal } \\
\text { patent }\end{array}$ & 0.19 & 0.12 \\
\hline Firm knowledge stock & $\begin{array}{l}\text { For each firm, this is the number of patents granted (by } \\
\text { application year) }\end{array}$ & 26.33 & 28.80 \\
\hline Patent originality & $\begin{array}{l}1 \text { - Herfindahl of each patent's backward citations } \\
\text { (Henderson et al. 1998), adjusted for bias, as per Hall and } \\
\text { Trajtenberg (2005) }\end{array}$ & 0.54 & 0.33 \\
\hline Patent complexity & $\begin{array}{l}\text { For each patent, this is Fleming and Sorenson's (2004) } \\
\text { measure of innovation complexity (see text) }\end{array}$ & 0.24 & 0.36 \\
\hline $\begin{array}{l}\text { Patent references to the } \\
\text { scientific literature }\end{array}$ & $\begin{array}{l}\text { For each patent, the number of references made to the } \\
\text { scientific literature. A measure of dependence upon scientific } \\
\text { knowledge }\end{array}$ & 32.96 & 47.27 \\
\hline
\end{tabular}


Table 3

Pair-wise Correlations

\section{A. For the variables in Table 4}

\begin{tabular}{|c|c|c|c|c|c|c|}
\hline \multirow{2}{*}{$\begin{array}{l}\text { (1) Firm knowledge brokering stock } \\
\text { (t) }\end{array}$} & (1) & (2) & (3) & (4) & (5) & (6) \\
\hline & & & & & & \\
\hline (2) Equity alliances stock (t-2) & $0.43^{*}$ & & & & & \\
\hline $\begin{array}{l}\text { (3) Venture capital inflows stock (t- } \\
\text { 2) }\end{array}$ & 0.08 & $0.53 *$ & & & & \\
\hline $\begin{array}{l}\text { (4) Hired inventors with different } \\
\text { technical knowledge stock }(\mathrm{t}-2)\end{array}$ & $0.67 *$ & $0.40^{*}$ & $0.22 *$ & & & \\
\hline $\begin{array}{l}\text { (5) Number of therapeutic areas (t- } \\
\text { 2) }\end{array}$ & $0.56^{*}$ & $0.51 *$ & $0.26^{*}$ & $0.70^{*}$ & & \\
\hline (6) Funding ease dummy & $0.52 *$ & $0.10^{*}$ & 0.06 & $0.26^{*}$ & $0.13^{*}$ & \\
\hline $\begin{array}{l}\text { (7) Overlap with initial technology } \\
\text { focus }(t-2)\end{array}$ & $-0.21 *$ & -0.10 & $-0.12 *$ & $-0.36^{*}$ & $-0.35^{*}$ & $-0.14 *$ \\
\hline
\end{tabular}

B. For the variables in Table 5

\begin{tabular}{|c|c|c|c|c|c|c|c|c|c|c|c|}
\hline \multirow{2}{*}{\multicolumn{12}{|c|}{$\begin{array}{l}\text { (1) External forward } \\
\text { citations }\end{array}$}} \\
\hline & & & & & & & & & & & \\
\hline $\begin{array}{l}\text { (2) Firm knowledge } \\
\text { brokering }\end{array}$ & $0.07 *$ & & & & & & & & & & \\
\hline $\begin{array}{l}\text { (3) Wholesale knowledge } \\
\text { brokering }\end{array}$ & -0.01 & $0.09 *$ & & & & & & & & & \\
\hline $\begin{array}{l}\text { (4) Partial knowledge } \\
\text { brokering }\end{array}$ & $0.06^{*}$ & $0.18^{*}$ & $-0.25^{*}$ & & & & & & & & \\
\hline $\begin{array}{l}\text { (5) Equity alliances stock } \\
\text { (t) }\end{array}$ & 0.01 & $-0.25^{*}$ & -0.02 & $0.30 *$ & & & & & & & \\
\hline $\begin{array}{l}\text { (6) Venture capital inflows } \\
\text { stock (t) }\end{array}$ & 0.01 & $-0.10^{*}$ & $0.23 *$ & $-0.04 *$ & $0.28 *$ & & & & & & \\
\hline $\begin{array}{l}\text { (7) Firm knowledge stock } \\
\text { (t) }\end{array}$ & -0.01 & $-0.40 *$ & $0.11^{*}$ & $0.08^{*}$ & $0.38 *$ & $0.16^{*}$ & & & & & \\
\hline $\begin{array}{l}\text { (8) Number of therapeutic } \\
\text { areas }\end{array}$ & $-0.05 *$ & $-0.16^{*}$ & $-0.05 *$ & $0.24 *$ & $0.34 *$ & $-0.07 *$ & $0.45^{*}$ & & & & \\
\hline (9) Patent originality & $0.07 *$ & $0.07 *$ & $0.11^{*}$ & $0.27 *$ & $0.10^{*}$ & $0.08^{*}$ & $0.05 *$ & $0.06^{*}$ & & & \\
\hline (10) Patent complexity & $-0.07 *$ & 0.02 & 0.00 & 0.02 & 0.02 & 0.03 & -0.01 & $0.12 *$ & $-0.06^{*}$ & & \\
\hline $\begin{array}{l}\text { (11) Patent references to } \\
\text { the scientific literature }\end{array}$ & -0.01 & $-0.05^{*}$ & -0.02 & $0.10 *$ & $0.13 *$ & $-0.06 *$ & $0.08^{*}$ & $0.19 *$ & 0.03 & 0.01 & \\
\hline $\begin{array}{l}\text { (12) Hired inventors with } \\
\text { different technical } \\
\text { knowledge stock }\end{array}$ & 0.02 & $-0.09^{*}$ & $0.07 *$ & $0.16^{*}$ & $0.24 *$ & -0.01 & $0.32 *$ & $0.57 *$ & $0.07 *$ & $0.11 *$ & $0.07 *$ \\
\hline
\end{tabular}

* denotes statistical significance at the 5\% level 
Table 4

Knowledge Brokering Antecedents

(Firm-Year Level of Analysis)

\begin{tabular}{|c|c|c|c|c|}
\hline \multirow[b]{2}{*}{ Independent variables } & \multicolumn{4}{|c|}{$\begin{array}{l}\text { Dep. Var.: Firm Knowledge Brokering Stock } \\
\text { (Estimation Method: Firm Fixed Effects OLS) }\end{array}$} \\
\hline & (4-1) & (4-2) & (4-3) & (4-4) \\
\hline $\begin{array}{l}\text { Equity alliances stock (t- } \\
\text { 2) }\end{array}$ & $\begin{array}{l}2.523^{* * * *} \\
(0.713)\end{array}$ & & & $\begin{array}{l}2.640 * * * \\
(0.705)\end{array}$ \\
\hline $\begin{array}{l}\text { Venture capital inflows } \\
\text { stock }(\mathrm{t}-2)\end{array}$ & & $\begin{array}{r}0.250 \\
(0.174)\end{array}$ & & $\begin{array}{c}0.026 \\
(0.169)\end{array}$ \\
\hline $\begin{array}{l}\text { Hired inventors with } \\
\text { different technical } \\
\text { knowledge stock }(\mathrm{t}-2)\end{array}$ & & & $\begin{array}{l}0.791 * * * \\
(0.112)\end{array}$ & $\begin{array}{l}0.806 * * * \\
(0.109)\end{array}$ \\
\hline $\begin{array}{l}\text { Number of therapeutic } \\
\text { areas }\end{array}$ & $\begin{array}{l}2.563 * * * \\
(0.244)\end{array}$ & $\begin{array}{l}2.909 * * * \\
(0.224)\end{array}$ & $\begin{array}{l}1.050 * * * \\
(0.339)\end{array}$ & $\begin{array}{c}0.579 * \\
(0.349)\end{array}$ \\
\hline Funding ease dummy & $\begin{array}{l}9.252 * * * \\
(1.305)\end{array}$ & $\begin{array}{l}9.711^{* * * *} \\
(1.325)\end{array}$ & $\begin{array}{l}8.146^{* * *} \\
(1.236)\end{array}$ & $\begin{array}{l}7.388 * * * \\
(1.217)\end{array}$ \\
\hline $\begin{array}{l}\text { Overlap with initial } \\
\text { technology focus }\end{array}$ & $\begin{array}{l}-4.523 * * \\
(2.250)\end{array}$ & $\begin{array}{l}-4.474 * * \\
(2.301) \\
\end{array}$ & $\begin{array}{l}-2.903 \\
(2.125)\end{array}$ & $\begin{array}{l}-2.643 \\
(2.071)\end{array}$ \\
\hline Firm fixed effects & Yes (18) & Yes (18) & Yes (18) & Yes (18) \\
\hline Constant & $\begin{array}{l}-0.448 \\
(1.829)\end{array}$ & $\begin{array}{l}-1.266 \\
(2.703) \\
\end{array}$ & $\begin{array}{l}-2.481 \\
(1.724) \\
\end{array}$ & $\begin{array}{l}-5.088 * * \\
(2.496) \\
\end{array}$ \\
\hline R-squared & 0.710 & 0.698 & 0.745 & 0.854 \\
\hline \# observations & 279 & 279 & 279 & 279 \\
\hline
\end{tabular}

$*, * *$ and $* * *$ denote statistical significance at the $10 \%, 5 \%$ and $1 \%$ level, respectively. 
Table 5

Knowledge Brokering Innovation Impact

External Forward Citations within 5 Years of Patent Issue

\begin{tabular}{|c|c|c|c|c|}
\hline \multirow[b]{2}{*}{ Independent variables } & \multicolumn{4}{|c|}{$\begin{array}{c}\text { Dep. Var.: External Forward Citations } \\
\text { (Estimation Method: Random Effects Poisson) }\end{array}$} \\
\hline & $(5-1)$ & $(5-2)$ & $(5-3)$ & $(5-4)$ \\
\hline \multicolumn{5}{|l|}{ Firm level variables } \\
\hline Firm knowledge brokering & $\begin{array}{l}1.216^{* * * *} \\
(0.271)\end{array}$ & $\begin{array}{l}0.943 * * * \\
(0.282)\end{array}$ & $\begin{array}{l}1.024 * * * \\
(0.321)\end{array}$ & \\
\hline $\begin{array}{l}\text { Firm knowledge brokering } \\
\text { squared }\end{array}$ & $\begin{array}{l}-1.458 * * * \\
(0.345)\end{array}$ & $\begin{array}{l}-1.174 * * * \\
(0.349)\end{array}$ & $\begin{array}{l}-1.356 * * * \\
(0.361)\end{array}$ & \\
\hline $\begin{array}{l}\text { Wholesale knowledge } \\
\text { brokering }\end{array}$ & & & & $\begin{array}{l}-0.600 * * * \\
(0.203)\end{array}$ \\
\hline Partial knowledge brokering & & & & $\begin{array}{l}0.809 * * * \\
(0.133)\end{array}$ \\
\hline Equity alliances stock(t) & & & $\begin{array}{l}0.091 * * * \\
(0.013)\end{array}$ & $\begin{array}{l}0.081 * * * \\
(0.014)\end{array}$ \\
\hline $\begin{array}{l}\text { Venture capital inflows } \\
\operatorname{stock}(\mathrm{t})\end{array}$ & & & $\begin{array}{c}0.003 \\
(0.002) \\
\end{array}$ & $\begin{array}{l}0.005 * * * \\
(0.002)\end{array}$ \\
\hline $\begin{array}{l}\text { Hired inventors with } \\
\text { different technical } \\
\text { knowledge stock }(\mathrm{t})\end{array}$ & & & $\begin{array}{l}0.008 * * * \\
(0.002)\end{array}$ & $\begin{array}{l}0.008 * * * \\
(0.002)\end{array}$ \\
\hline Firm knowledge stock & & $\begin{array}{l}-0.002 * * \\
(0.001)\end{array}$ & $\begin{array}{l}-0.034 * * * \\
(0.001)\end{array}$ & $\begin{array}{l}-0.004 * * * \\
(0.001)\end{array}$ \\
\hline Number of therapeutic areas & & $\begin{array}{c}0.001 \\
(0.005) \\
\end{array}$ & $\begin{array}{l}-0.016 * * * \\
(0.006) \\
\end{array}$ & $\begin{array}{l}-0.015 * * * \\
(0.006)\end{array}$ \\
\hline \multicolumn{5}{|l|}{ Patent level variables } \\
\hline Patent originality & $\begin{array}{l}0.406^{* * * *} \\
(0.053) \\
\end{array}$ & $\begin{array}{l}0.397 * * * \\
(0.053) \\
\end{array}$ & $\begin{array}{l}0.389 * * * \\
(0.054) \\
\end{array}$ & $\begin{array}{l}0.324 * * * \\
(0.056)\end{array}$ \\
\hline Patent complexity & & & $\begin{array}{l}-0.764 * * * \\
(0.174)\end{array}$ & $\begin{array}{l}-1.249 * * \\
(0.524)\end{array}$ \\
\hline $\begin{array}{l}\text { Patent references to the } \\
\text { scientific literature }\end{array}$ & & & $\begin{array}{l}0.001 * * * \\
(0.000)\end{array}$ & $\begin{array}{l}0.001 * * * \\
(0.000)\end{array}$ \\
\hline \multicolumn{5}{|l|}{ Interaction terms } \\
\hline $\begin{array}{l}\text { Firm knowledge brokering } * \\
\text { patent complexity }\end{array}$ & & & $\begin{array}{l}1.478 * * \\
(0.724) \\
\end{array}$ & \\
\hline $\begin{array}{l}\text { Wholesale knowledge } \\
\text { brokering * patent } \\
\text { complexity }\end{array}$ & & & & $\begin{array}{l}5.933 * * * \\
(1.231)\end{array}$ \\
\hline $\begin{array}{l}\text { Partial knowledge brokering } \\
* \text { patent complexity }\end{array}$ & & & & $\begin{array}{l}-1.265 * \\
(0.703)\end{array}$ \\
\hline \multicolumn{5}{|l|}{ Other } \\
\hline $\begin{array}{l}\text { Dummy for each patent } \\
\text { application year }\end{array}$ & Yes (23) & Yes (23) & Yes (23) & Yes (23) \\
\hline $\begin{array}{l}\text { Dummy for each primary } \\
\text { US patent class }\end{array}$ & Yes (49) & Yes (49) & Yes (49) & Yes (49) \\
\hline Constant & $\begin{array}{l}-2.628 * * \\
(1.036) \\
\end{array}$ & $\begin{array}{l}-3.060 * * * \\
(1.043) \\
\end{array}$ & $\begin{array}{l}-0.446 \\
(0.344) \\
\end{array}$ & $\begin{array}{c}0.403 \\
(0.351) \\
\end{array}$ \\
\hline Log likelihood & -4121.14 & -4108.56 & -4054.30 & -4021.65 \\
\hline \# observations & 1501 & 1501 & 1498 & 1498 \\
\hline
\end{tabular}

$*, * *$ and $* * *$ denote statistical significance at the $10 \%, 5 \%$ and $1 \%$ level, respectively. 